\title{
TRANSFIGURATIO DOMINI IN THE APSE AT MOUNT SINAI AND THE SYMBOLISM OF LIGHT* Jerzy Miziołek
}

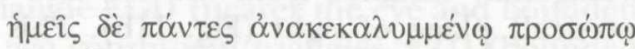

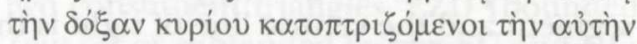

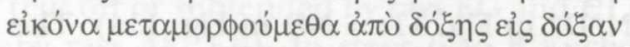

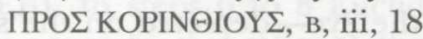

I N THE MIDDLE of the sixth century the Emperor Justinian founded a monastery on Mount Sinai to commemorate the traditional site on which God had revealed himself to Moses. ${ }^{1}$ It was probably before Justinian's death in 565 that the monastery's church was decorated with mosaics which have survived almost intact to this day. ${ }^{2}$ The mosaics portray in the apse the Transfiguration (Pl. 2b), on the triumphal arch the Lamb of God, and on the wall above it Moses on Mount SinaiHoreb (Pl. 2a). ${ }^{3}$ The exegetical statement implicit in representing the Transfiguration on Mount Tabor in a church at Mount Sinai is developed iconographically by its juxtaposition with the event on Mount Sinai-Horeb-a juxtaposition which may be likened to the opening sentence of a complex visual message. It will be argued in this paper that its focus is the Sun of justice.

* This paper is based on the fourth chapter of my Ph.D thesis Sol Verus. Studia nad ikonografia Chrystusa w sztuce pierwszego tysiaclecia (Studies on the iconography of Christ in the art of the First Millennium), Jagiellonian University, Cracow 1987. I am most grateful to my supervisor, Professor Lech Kalinowski, for his support and for many stimulating suggestions. My warm thanks to Dr Christopher Ligota and Dr Robert Anderson for their help and encouragement - to them I dedicate this article. I should also like to express my gratitude to Professor Kurt Weitzmann for his valuable comments. I am indebted to the Warburg Institute and the Lanckoroński Foundation for financial assistance.

The following abbreviations are used throughout:

CCSL: Corpus Christianorum. Series Latina, Turnhout $1954 \mathrm{ff}$.

CSEL: Corpus Scriptorum Ecclesiasticorum Latinorum, Vienna 1866ff.

PG: $\quad$ Patrologia Graeca, ed. J. P. Migne, Paris $1857 \mathrm{ff}$.

PL: $\quad$ Patrologia Latina, ed. J. P. Migne, Paris $1844 \mathrm{ff}$.

-1 For information on the architecture, the dedication of the monastery and the church see G. H. Forsyth, 'The Monastery of St. Catherine at Mount Sinai. The Church and Fortress of Justinian', Dumbarton Oaks Papers, xxii, 1968, pp. 1-19; idem in G. H. Forsyth and K. Weitzmann with I. Ševčenko and F. Andereg, The
Monastery of Saint Catherine at Mount Sinai. The Church and Fortress of Justinian. Plates, Ann Arbor 1973, pp. 5-10. See also J. Galey, Sinai and the Monastery of St Catherine, London 1980, with texts by G. H. Forsyth and K. Weitzmann.

2 See K. Weitzmann, 'The Mosaic in St Catherine's Monastery on Mount Sinai', Proceedings of the American Philosophical Society, cx, 1966, pp. 392-405; Weitzmann in Forsyth \& Weitzmann (as in n. 1), pp. 11-18. See also C. Ihm, Die Programme der christlichen Apsismalerei vom vierten Jahrhundert bis zur Mitte des achten Jahrhunderts, Wiesbaden 1960, pp. 69ff and 196f, with previous bibliography on p. 197. See also I. Ševčenko, 'The Early Period of the Sinai in the Light of its Inscriptions', Dumbarton Oaks Papers, xx, 1966, pp. 255-64; E. Kitzinger, Byzantine Art in the Making, Cambridge Mass. 1977 , pp. 99-103 and figs 177-79. After cleaning of the mosaics by American expeditions directed by Professors G. H. Forsyth and K. Weitzmann from the Universities of Chicago and Princeton, it was maintained that the apse mosaic of Sinai had undergone no major restoration in thirteen hundred years. For the best colour and black-and-white reproductions of the mosaics see Forsyth \& Weitzmann (as in n. 1), passim.

3 On absidal Transfigurations see $\mathrm{Ihm}$ (as in n. 2), pp. $69-75$. 
The mandorla in the centre of the apse shows Christ facing outwards (Pl. 2b) dressed in a bluish-white tunic with golden clavi, and a pallium. His face, with dark moustache and pointed beard, dark hair swept back, is depicted against a golden cross. Christ is giving the Greek blessing with his right arm bent at the elbow, and right hand raised to his breast, while his left hand, with arm slightly bent and lowered, holds the hem of his garment. The mandorla consists of three concentric blue ovals shading to a lighter blue at the edge. From the figure of Christ emanate seven or eight symmetrical silver rays which extend beyond the mandorla. The five accompanying figures are identified by inscriptions above their heads. To the right and left of Christ stand Elijah and Moses, Elijah wearing a tunic and fur coat, Moses a tunic and pallium. They are both depicted as old with beards and grey hair, and both raise their right hand in a gesture of speech. The three Disciples beneath the mandorla express astonishment: they have fallen to their knees and are trying to direct their gaze towards the vision without quite succeeding. Each witness to the vision is lit by one of the rays which changes the colour of his clothing in the area of its impact. Apart from a narrow band of green under the feet of Moses, Elijah and the Disciples, the background of the composition is evenly golden. It is strictly symmetrical and as such a typical piece of apsidal decoration. The dynamism of the scene is a striking portrayal of the atmosphere of wonder on Mount Tabor.

Below the scene is the following dedicatory inscription:

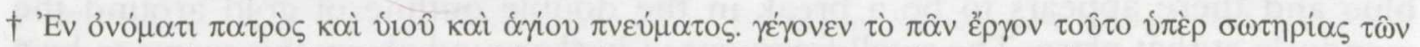

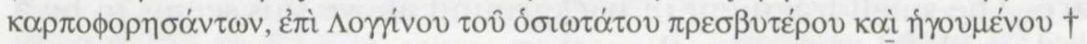

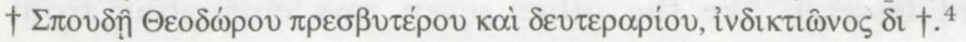

The apse is framed with thirty-one medallion busts of figures identified by inscriptions. In the lower margin are the figures of David, all the major and minor prophets, the hegoumenos Longinus and John the Deacon, ${ }^{5}$ and in the upper the remaining Apostles and Evangelists. Above the head of Christ, between the images of Andrew and Paul, one more medallion bears a golden Greek cross against a background of three concentric blue spheres which darken towards the centre. The triumphal arch has a medallion with the Lamb of God (Pl. 2a) in three-quarter view, set against a Greek cross, and on either side is a winged angel bearing a sceptre and cross-orb. Medallion busts of the Virgin and John the Baptist below the angels complete the composition. The area above the arch contains two Sinai scenes: the Burning Bush and Moses receiving the Law. The strictly symmetrical composition of the apse and triumphal arch has a vertical axis formed by David, Christ, the Greek cross and the Lamb of God.

4 'In the Name of (God) the Father, the Son and the Holy Ghost. This entire work was executed for the salvation of the donor(s) in the days of Longinus, the most holy presbyter and hegoumenos, by the effort of Theodore, priest and second-in-command, indiction fourteen.' The inscription is analysed by Ševčenko (as in n. 2), pp. 255ff, esp. pp. 259-61; Ševčenko in Forsyth \& Weitzmann (as in n. 1), pp. 19-20; see also A. Guillou,
'Le Monastère de la Theotokos au Sinai', Mélanges d'archéologie et d'histoire, lxvii, 1955, pp. 217ff, who thinks that the lower part of the inscription with the name of Theodoros is modern and that it dates from 1840-1841, a theory rejected by Ševčenko.

5 For information about this character, sometimes erroneously identified with John Climacus, see Weitzmann (as in n. 2), p. 403. 
Interesting observations have been made on the iconography and meaning of the Sinai mosaics by various scholars, ${ }^{6}$ above all Kurt Weitzmann, in what is so far the most comprehensive interpretation. ${ }^{7}$ According to Weitzmann, six 'layers' of meaning can be discerned; however, he has almost completely neglected the problem of the light which, in the form of wide and distinctly drawn rays, emanates from the figure of Christ. Though never a subject of detailed study, the problem has been raised by a number of authors, some of whom argue that the rays of the Transfiguration symbolise the theophany and reveal God's glory as well as the divine nature of Christ, presenting him as Kyrios elevated by God the Father. ${ }^{8}$ Although another scholar has recently emphasised the relation between light and the dogma of the Holy Trinity, ${ }^{9}$ all these observations, however correct, remain fragmentary. The purpose of this article is to offer a more comprehensive interpretation.

An important element in the problem of the Sinai Transfiguration is the number of the rays. Some art historians observe only seven, ${ }^{10}$ but others are of the opinion that there may be eight. ${ }^{11}$ Part of the mosaic above Christ's head is missing. A hook was at some point driven into the wall to hang a lamp, but in time it rusted and partly destroyed the nimbus and the mandorla. On the edge of the area of loss there is most probably a remnant of an eighth ray emerging vertically behind Christ's head or nimbus. The outermost oval of the mandorla has a zone of lighter blue and there appears to be a break in the double outline of gold around the mandorla at that place. The small fragment of background above this seems to be a mixture of silver and gold tesserae like the other seven rays emanating from Christ. ${ }^{12}$

The Sinai mosaics are the earliest known example of a Transfiguration with rays. ${ }^{13}$ Neither the rays nor the mandorla appear in two earlier representations of

6 See for instance A. Grabar, Martyrium. Recherches sur le culte des reliques et l'art chrétien antique, II, Iconographie, Paris 1946, pp. 190-96; G. Soteriou, 'To mosaikon tes Metamorfoseos tou katholikou tes Mones tou Sina', Atti dello VIII congresso internazionale di studi bizantini, Rome 1953, pp. 246-52 and pls lxxiv-lxxxviii; E. Dinkler, Das Apsismosaik von S. Apollinare in Classe, Cologne 1964, pp. 26ff; S. Dufrenne, 'La manifestation divine dans l'iconographie byzantine de la Transfiguration', in Nicée II, 787-1987, eds F. Boespflug and N. Lossky, Paris 1987, pp. 185-206: on the Sinai Transfiguration, passim; on rays, pp. 200ff. See also Ihm (as in n. 2), pp. $69 \mathrm{ff}$ and 195-97; F. Gerke, 'La Metamorfosi nell'arte protobizantina', Corsi di cultura sull'arte ravennate e bizantina, vii, 1960, pp. 99-111.

7 Weitzmann (as in n. 2), pp. 400-05; idem, in Forsyth \& Weitzmann (as in 1), pp. 11-18. A full publication of the mosaics by Weitzmann is awaited.

. 8 Dinkler (as in n. 6), pp. 26-29 and 48; Dufrenne (as in n. 6), passim; see also J. Myslivec, 'Verklärung Christi', Lexikon der christlichen Ikonographie, eds E. Kirschbaum et al., Rome 1968ff, iv, col. 416; and W. C. Loerke, 'Observations on the Representation of Doxa in the Mosaics of S. Maria Maggiore, Rome, and St Catherine's Sinai', Gesta, xx, 1, 1981, pp. 20-21.

9 F. de' Maffei, 'L'Unigenito consustanziale al Padre nel programma trinitario dei perduti mosaici del bema della Dormizione di Nicea e il Cristo trasfigurato del Sinai, II', Storia dell'arte, xlvi, 1982, pp. 185-200.

10 See for example, Ihm (as in n. 2), p. 195; Dinkler (as in n. 6), p. 27; W. F. Volbach and J. LafontaineDosogne, Byzanz und der christliche Osten, iii, Berlin 1968, p. 167; Myslivec (as in n. 8), col. 416.

11 Loerke (as in n. 8), p. 21; W. Weber, Symbolik in der abendländischen und byzantinischen Kunst. Von Sinn und Gestalt der Aureole, Basle 1981, p. 52.

12 For information on damage to the mosaic above the head of Christ see Weitzmann (as in n. 2), pp. 397-400. In Weitzmann's paper there is no information on the number of rays, nor on the ray above the mandorla. For detailed information on the mosaic, I should like to thank Ernest J. W. Hawkins who showed me colour slides and discussed this point with me.

13 On the iconography of the Transfiguration see A. de Waal, 'Zur Ikonographie der Transfiguration in der alteren Kunst', Römische Quartalschrift, xvi, 1902, pp. 25-40; G. Millet, Recherches sur l'iconographie de l'Évangile aux XIVe, XVe, et XVIe siècles d'après les monuments de Mistra, de la Macédoine et du Mont Athos, 2nd edn, Paris 1960, pp. 216-31; Dinkler (as in n. 6), pp. 25-50; G. Schiller, Ikonographie der christlichen Kunst, Gütersloh 1966ff, i, pp. 155-61; Y. Christe, Les grands portails romans. Etude sur l'iconographie des theophanies romanes, Geneva 1969, pp. 97-104; Myslivec (as in n. 8), cols 
the subject, namely on the Brescia casket ${ }^{14}$ and on the wooden doors of Santa Sabina in Rome. ${ }^{15}$ It is not clear whether rays were introduced in the sixth-century mosaic of the Transfiguration in the apse of the Chiesa del Salvatore (Stefania) in Naples, known only from the ninth-century description by John the Deacon, ${ }^{16}$ or in a badly preserved mosaic of the same date on the eastern facade above the central apse of the Euphrasian basilica in Poreč (Parenzo). ${ }^{17}$ Rays are mentioned as part of the Transfiguration scene in one of the domes of the Apostles' church in Constantinople but their number and arrangement are not specified. ${ }^{18}$ The motif of rays appears on a Syrian cross discovered in the Crimea dating from between the sixth and the eighth century. ${ }^{19}$ Although the rays emanating from Christ are arranged differently from those in the Sinai mosaics, and do not extend beyond the mandorla, there seem to be eight of them. Moreover there are numerous later examples of the Transfiguration scene with eight symmetrically arranged rays, dating from the eleventh, twelfth and following centuries: for instance, the mosaic in one of the squinches of the church at Daphni near Athens, ${ }^{20}$ a panel on the bronze door of San Paolo fuori le mura in Rome (Pl. 4a), ${ }^{21}$ and a miniature in the Psalter of Queen Melisende. ${ }^{22}$ An interesting example may also be found in the Sinai monastery itself-a beautiful small icon probably dating from the second half of the eleventh century (Pl. 4b). ${ }^{23}$ A number of other Transfiguration scenes with five,

416-421 (with bibliography); Weber (as in n. 11), pp. 47-92; Dufrenne (as in n. 6), pp. 185-206. See also J. Elsner, 'Image and Iconoclasm in Byzantium', Art History, xi, 1988, pp. 474-77.

14 R. Delbrück, Probleme der Lipsanothek in Brescia, Bonn 1952, pp. 32ff; W. F. Volbach, Elfenbeinarbeiten der Spätantike und des frühen Mittelalters, Mainz 1952, no. 107; Grabar 1946 (as in n. 6), pp. 165, 191, is of the opinion that the first representation of the Transfiguration was made in the apse of the church on Mount Tabor (4th century?).

15 Dinkler (as in n. 6), p. 32 and fig. 7; G. Jeremias, Die Holztür der Basilica S. Sabina in Rom, Tübingen 1980, pp. 77f, fig. 67.

16 'Gesta Episcoporum Neapolitanum', I, 16, xxii, ed. G. Waitz, in Monumenta Germaniae Historica: Scriptores Rerum Longobardarum et Italicarum Saec. VI-IX, Hannover 1878 p. 410: 'Hic Johannes (Bishop AD 535-555) absidam ecclesiae Stephaniae, lapsam ex incendio reformavit. In qua ibidem ex musivo depinxit transfigurationem Domini Nostri'. See also Ihm (as in n. 2), pp. 71f; Dinkler (as in n. 6), pp. 26f; G. Bovini, 'Mosaici paleocristiani scomparsi di Napoli', Corsi di cultura sull'arte ravennate e bizantina, xiv, 1967, pp. 27-30.

17 B. Malajoli, La basilica eufrasiana di Parenzo, Parenzo 1940 , p. 33 and fig. 33; J. Maksimovič, 'Ikonografia i program mosaika u Poreču' in Mélanges G. Ostrogorsky, ii, Belgrade 1964, pp. 247ff; Elsner (as in n. 13), p. 274 and fig. 5 .

18 Nicolaus Mesarites, Description of the Church of the Holy Apostles at Constantinople, ed. and transl. G. Downey, in Transactions of the American Philosophical Society, N.S. xlvii, 6,1957 , pp. 871-72. On the date of this mosaic -7 th, 9 th or 12 th century? - see H. Maguire, 'Truth and Convention in Byzantine Descriptions of Works of Art', Dumbarton Oaks Papers, xxviii, 1974, pp. 123-24.
19 Grabar 1946 (as in n. 6), p. 193 and fig. lxii, 7; C. O. Nordström, Ravennastudien. Ideengeschichtliche und ikonographische Untersuchungen über Mosaiken von Ravenna, Stockholm 1953, p. 126 and fig. 28f. For discussion of the date, see A. D. Kartsonis, Anastasis. The Making of an Image, Princeton 1986, p. 104 n. 23. There is an interesting, but only partially preserved, example of the Transfiguration scene in the Lectionary fragment at the Public Library in Leningrad (MS 21) belonging to the 10 th century but most probably, as Morey suggests, reflecting an earlier model; see C. R. Morey, 'Notes on East Christian Miniatures', Art Bulletin, xi, 1929, p. 89, fig. 103.

20 E. Diez and O. Demus, Byzantine Mosaics in Greece. Hosios Lucas and Daphni, Cambridge Mass. 1931, pp. 60-62 and figs 89-91.

21 G. Matthiae, La porte bronzee bizantine in Italia, Rome 1971 , p. 78 and fig. 21; de Waal (as in n. 13), p. 34.

22 British Museum, MS Egerton 1139, fol. $4^{\mathrm{v}}$; see $\mathrm{H}$. Buchthal, Miniature Painting in the Latin Kingdom of Jerusalem, Oxford 1957, pl. 4b.

23 K. Weitzmann, 'A Metamorphosis Icon or Miniature on Mt. Sinai', Starinar, N.S. xx, 1969, pp. 415-21, fig. 1; idem, Illustrated Manuscripts at St Catherine's Monastery on Mount Sinai, Collegeville 1973, p. 23, fig. 30. A nearly identical scene of the Transfiguration occurs on a mosaic icon in the Louvre dating from the 12th or 13th century, see K. Hoffmann, The Year 1200. A Centennial Exhibition at the Metropolitan Museum of Art, i, New York 1970 , no. 239 (with previous bibliography). For other examples see Schiller (as in n. 13), i, figs 410, 411, 415. It is also worth noting representations with the motif of imago Christi set against two overlapping rectangles which form an eight-pointed star, e.g. a miniature from the theological works of the Emperor John VI Cantacuzene, in the Bibliothèque Nationale, MS gr. 1242 , fol. $92^{\mathrm{v}}$ from the 14 th century, but probably based 
six, ten and up to as many as twenty-four or more rays are extant. ${ }^{24}$ There are also numerous examples with seven symmetrically arranged rays. ${ }^{25}$ To sum up, it seems not unreasonable to assume, on the basis of the comparative material, and of what remains above the mandorla, that originally eight rays emanated from the Sinai Christ.

What are the iconographic antecedents of the Sinai Transfiguration? It has been suggested that representations of the rising sun popular in antique art may have served as models. ${ }^{26}$ This is not fully convincing, for examples of Helios as a solar charioteer differ considerably from the Sinai scene. There is a similarity between the wide rays in the Transfiguration and the beams radiated by the Phoenix in the Antioch mosaic and by the personification of the sun in a miniature in the Vatican Vergil, both of which date from the fifth century. ${ }^{27}$ Some valuable general observations concerning the symbolism of rays in the Capella Palatina Transfiguration in Palermo, and their relation to the christogram seen as a solar sign, have been made; but they do not explain the problem though they point to interesting possibilities. ${ }^{28}$

The suggestion of solar ancestry may be examined in a modified form: the Sinai rays derive from representations of the sun as a circle with eight rays or as an eightpointed star-representations which date back as far as the art of the Ancient East. One of the earliest examples is an Old Babylonian relief, now in the Louvre, which depicts the sun as a disk with eight pointed rays. ${ }^{29}$ A slightly different sun motif, common in the Ancient East, occurs on a Neo-Hittite stele from Northern Syria, now in Berlin. ${ }^{30}$ Here it is a rosette within a winged disk, and the eight rays have the form of petals. There were also many representations of the sun radiating eight beams from its central circle, and it seems that similar motifs have been found on objects dating from prehistoric times made in Northern Europe. ${ }^{31}$

on a 10th-century prototype; see J. Beckwith, Early Christian and Byzantine Art, Harmondsworth 1979, p. 330 and fig. 294.

${ }^{24}$ See e.g. W. Krönig, 'Zur Transfiguration der Cappella Palatina', Zeitschrift für Kunstgeschichte, xix, 1956, figs 1 and 2 (Capella Palatina in Palermo); M. Restle, Die byzantinische Wandmalerei in Kleinasien, ii, Recklinghausen 1967, figs 175 and 204 (rock churches in Cappadocia); Schiller (as in n. 13), i, fig. 418 (Ingeborg Psalter, Chantilly, Musée Condé, MS 9 [1695], fol. 20v) See also Millet (as in n. 13), pp. 216-31.

25 K. Weitzmann, 'The Study of Byzantine Book Illumination, Past, Present and Future', in The Place of Book Illumination in Byzantine Art, Princeton 1975, fig. 31 (Venice, S. Lazzaro, MS 1400, fol. $4^{\mathrm{v}}$ ), fig. 32; Mount Athos, Iviron, MS 1, fol. 303v; Krönig (as in n. 24), fig. 3 (mosaic in Monreale); Dinkler (as in n. 6), fig. 16 (Florence, Bibl. Laurenziana, Plut. VI, 23, fol. 34v). See also Schiller (as in n. 13), i, fig. 417 (Bible from Floreffe; London, British Museum, MS Add. 17733-38, fol. 4) -in this last example, the rays are not symmetrical. It may be pointed out that the Transfiguration scene on the door of S. Paolo fuori le mura, the Mosaic from Daphni and the Louvre icon, are very often considered as being seven-rayed, even though an eighth ray can be clearly seen. See Matthiae (as in $n$. 21), p. 78; Krönig (as in n. 24), p. 167; Schiller (as in n. 13), i, p. 159. See also L. Hautecoeur, Mystique et architecture. Le symbolisme du cercle et de la coupole, Paris 1954 , p. 272.

26 A. Grabar, Christian Iconography. A Study of its Origins, Princeton 1968, p. 117. Also H. Gaidoz, 'Le dieu gaulois du soleil et le symbolisme de la roue', Revue archéologique, 3rd ser., vi, 1885 , pp. 16ff, and Hautecoeur (as in n. 25), pp. $188-89$ and 272 , have related the Transfiguration scene to the iconography of the sun, though not in the context of the Sinai mosaic. Their remarks are very general.

27 Loerke (as in n. 8), pp. 21 and 22, n. 34

28 Krönig (as in n. 24), pp. 162ff. See also W. Schöne, Über das Licht in der Malerei, Berlin 1954, pp. 77-78 and p. 80 n. 168.

29 H. Schäfer and W. Andrae, Die Kunst des alten Orients, Berlin 1935, fig. on p. 477; see passim for further examples. See also G. Contenau, 'La représentation des divinités solaires en Babylonie', Revue biblique, xiv, 1917, pp. 4ff: ('Un emblême fréquent dans les scènes ayant incontestablement trait à Samaš, est une étoile à huit branches.')

30 Schäfer and Andrae (as in n. 29), fig. on p. 564; cf. also G. Contenau, Manuel d'archéologie orientale, iii, Paris 1931, fig. 757.

31 J. Dechelette, Manuel préhistorique, celtique et galloromain, ii, Paris 1913, pp. $458 \mathrm{ff}$, pl. on p. 190 containing various sun motifs; J. Baltrušaitis, 'Quelques survivances 
An eight-pointed star or a circle with eight rays was frequently used to depict the sun in Greek and Roman art too. Good examples are a decadrachm obverse dating from around $500 \mathrm{BC}(\mathrm{Pl} .3 \mathrm{~d}),{ }^{32}$ and a vase from the fourth or third century BC found at Amissus (Pl. 3e). ${ }^{33}$ The coin shows the sun as a circle with eight rays above a two-wheeled cart, whereas the vase depicts the sun as a star placed between two smaller stars (Dioscuri), over the head of Alexander the Great-the new sun. Similar stars were used to decorate the diadems of the priests of Helios in Egypt. ${ }^{34}$ They also appear on Roman coins; suffice it to mention those of Constantine the Great, in both the Eastern and the Western parts of the Empire. Eight-pointed stars were placed above representations of triumphal arches and gates and have been related to the concept of Sol Dominus Imperii Romani. ${ }^{35}$ The sun as a circle with rays very often appears on contorniates. ${ }^{36}$ An example in the Vatican shows the head in profile of Alexander the Great as Hercules (Pl. 3c). ${ }^{37}$ At the tip of Alexander's chin is a circle, with eight ' $T$ ' shaped rays emanating from it, which can be taken to represent the sun. The letter ' $\mathrm{S}$ ' inscribed in the circle stands for Salus or Sol. In this instance the sun motif is used to symbolise prosperity brought by the rising sun. ${ }^{38}$

The sun as a circle with eight rays (or 'bunches' of rays), or as an eight-pointed star, is also a common motif in Christian art. Good examples can be found in three tenth-century manuscripts: the Joshua Roll, which is based on an early Christian archetype (Pl. 5a), ${ }^{39}$ the Gerona Beatus, ${ }^{40}$ and the Florence Cosmas (Pl. 4c). ${ }^{41}$ In the Joshua Roll the sun, depicted as a circle with eight linear rays, is placed amid the battle between Joshua's army and the Amorites. It also occurs as a circle, this time with triple 'bunches' of rays and the inscription 'H $\mathrm{H} \iota \varsigma$, , in the Florence Cosmas. In the miniature from the Beatus manuscript the sun appears in a symbolic context; the eight-pointed star is linked with a figure of the Woman of the Apocalypse. ${ }^{42}$ The

de symboles solaires dans l'art du moyen âge', Gazette des Beaux-Arts, 6th ser., xvii, 1937, pp. 75-82.

32 T. Gerassimov, Antique Coins Struck and in Circulation in the Bulgarian Lands, Sophia 1977, p. 7 and fig. 1.

33 F. Cumont, Recherches sur le symbolisme funéraire des romains, Paris 1942, p. 208 and pl. xvi, 1; S. Weinstock, Dirns Julius, Oxford 1971, p. 375 and pl. xxvii, 1.

34 Weinstock (as in n. 33), pp. 375-76 and pl. 26.

35 E. Baldwin Smith, Architectural Symbolism of Imperial Rome and the Middle Ages, Princeton 1956, pp. 46-47 and figs $42-43$.

36 A. Alföldi, Die Kontorniaten, Budapest 1943, nos 13, 76, 77, 133 etc. and p. 25; idem and E. Alföldi, Die Kontorniat-Medaillons, i, Katalog, Berlin 1976, pls 15, 9; $35,5-11 ; 37,3 ; 65,3 ; 86,4 ; 10 ; 91,9-10 ; 187,3 ; 189$, $5-6$. The number of rays in these representations varies from five to eight.

37 ibid., pl. 15, 9; see also F. J. Dölger, Sol Salutis, Gebet und Gesang im christlichen Altertum, 2nd edn, Münster i. W. 1925, pp. 395-96; M. Schapiro, 'Notes on Castelseprio', Art Bulletin, xxxix, 1957, p. 295 and fig. 5.

38 Dölger 1925 (as in n. 37), p. 395. For further examples see ibid., pp. 403-04; A. B. Cook, Zeus. A Study of Ancient Religion, ii, Cambridge 1925, pp. $629-30$ and fig. 535.

39 Bibl. Apost. Vat., MS Palat. gr. 431, sheet xii; see H. Leclercq, 'Astres', Dictionnaire d'archéologie chrétienne et de liturgie, i, 2, Paris 1924, fig. 1059. For a colour reproduction see A. Grabar, Byzantine Painting, New York 1957, p. 171. For information on the much debated and still controversial question of the origin of the Joshua Roll see K. Weitzmann, The Joshua Roll, A Work of the Macedonian Renaissance, Princeton 1948; M. Schapiro, 'The Place of the Joshua Roll in Byzantine History', Late Antique, Early Christian and Mediaeval Art, London 1980, pp. 49-66. See also C. R. Morey, Early Christian Art, Princeton 1953, pp. 69ff; V. N. Lasareff, 'Gli affreschi di Castelseprio', Sibrium, iii, 1956-1957, pp. 87-102 esp. 97ff.

40 Gerona, Cathedral Archives, fol. 171v, see M. Schapiro, 'The Beatus Apocalypse of Gerona', in Schapiro (as in n. 39), fig. 1 on p. 320; Schiller (as in n. 13), iv, 1, p. 80 and fig. 189. An eight-pointed star is sometimes linked with representations of the mighty angel 'with a face as it were of the sun' (Apocalypse x, 1); see W. Neuss, Die Apokalypse des Hl. Johannes in der altspanischen und altchristlichen Bibelillustration, ii, Münster i. W. 1931, pls lxxiv, 109 and lxxix, 116.

41 Biblioteca Laurenziana, Plut. 9, 28, fol. 103v; see C. O. Nordström, 'The Water Miracles of Moses in Jewish Legend and Byzantine Art', in No Graven Images, ed. J. Gutmann, New York 1971, pp. 291-92 and fig. 6.

42 On 'Mulier amicta sole' see Schiller (as in n. 13), iv, 1, pp. 77-84. Patristic texts on the subject are treated by H. Rahner, 'The Christian Mystery of the Sun and 
most important representations, however, can be found in two other illuminated codices: the ninth-century Sacra Parallela, probably based on early Christian models, ${ }^{43}$ and the Smyrna Physiologus, no longer extant, dating from the eleventh century. ${ }^{44}$ In both, the personified sun appears in a clipeus whence emanate eight rays. The image of Helios in the Sacra Parallela (Pl. 5d) occurs in a scene depicting the sickness of Hezekiah. A youthful face in a clipeus with eight symmetrically positioned 'bunches' of rays, one set of which falls on a sundial, is shown above the prophet in conversation with the ailing monarch. Even more significant in the context of the Sinai Transfiguration is the imago Solis from the Smyrna Physiologus (Pl. 5b). A bust of a young man, not a woman as has been suggested, is depicted in a clipeus above a Phoenix burning on a column. He holds an orb in his left hand, while the open palm of his right hand is raised to head level. ${ }^{45}$ The eight triple 'bunches' of rays seem to proceed not so much from the edge of the clipeus as from the solar figure itself. Though drawn rather perfunctorily, they appear to emanate from one point and form a kind of star. This image appears to be a faithful imitation of representations of the deity of light of the Sol Invictus type, common in late antique art, rather than an original creation by the eleventh-century illuminator of the codex. ${ }^{46}$ There is undoubtedly a close affinity between this image and the Sinai Christ except that the Physiologus illustration is only a bust, not a fulllength portrayal. It is fair to add that representations of the sun as a circle surrounded by seven rays or a seven-pointed star occur nearly as frequently as the eight-pointed star and the circle with eight rays. ${ }^{47}$

The preceding discussion by no means exhausts our examination of the iconographic antecedents of the Sinai mosaics because the examples given refer only to the figure of Christ and the rays, not to the whole scene in the apse. Let us return to the suggestion that representations of the theophany in Christian art were modelled on images of the rising sun. ${ }^{48}$ It is a fruitful idea that can perhaps be taken further. Consider the scene on a red-figure vase from central Italy, now in Parma, dated c. $400 \mathrm{BC}(\mathrm{Pls} \mathrm{3a}, \mathrm{b}) .{ }^{49}$ This is perhaps too remote to be a direct source of influence, but it provides a striking analogy. The rising sun (or the sun reappearing after an

Moon' in idem, Greek Myths and Christian Mystery, transl. B. Buttershaw, London 1963, pp. 154ff.

43 Paris, Bibliothèque Nationale, MS gr. 923, fol. 252v; see K. Weitzmann, The Miniatures of the Sacra Parallela. Parisinus Graecus 923, Princeton 1979, pl. lxxix, 357. On the sources of its illustration pp. 20ff.

44 J. Strzygowski, Der Bilderkreis des griechischen Physiologus, des Kosmas Indicopleustes und Oktateuch. Nach Handschriften der Bibliothek zu Smyrna, Leipzig 1899, p. 19 and pl. iv; R. van den Broek, The Myth of the Phoenix according to Classical and Early Christian Traditions, Études préliminaires aux religions orientales dans l'empire romain, xxiv, Leiden 1972 , p. 456 and pl. xxxvii. The manuscript was destroyed by fire in 1923 .

45 Strzygowski (as in n. 44), p. 19. Cf. Dölger 1925 (as in n. 37), p. 33.

46 cf. H. P. l'Orange, Studies on the Iconography of Cosmic Kingship in the Ancient World, Oslo 1953, figs 100 and 106; idem, 'Sol Invictus Imperator. Ein Beitrag zur Apotheose', in Likeness and Icon. Selected Studies in Classical and Early Medieval Art, Oslo 1973, pp. 325-44 and figs $1-2,4-7$.
47 See Weinstock (as in n. 33), pp. 375-76 and pl. 26 (seven-pointed star); M. V. Ščepkina, Miniatury Chludovskoj Psaltyry, facsimile, Moscow 1977, fol. 154 (a circle with seven rays). More common are representations of the personification of the sun with seven rays around the head; for examples see F. Cumont, Textes et monuments figurés relatifs aux mystères de Mithra, i, Brussels 1899, p. 123; F. J. Dölger, 'Das Sonnengleichnis in einer Weihnachtspredigt des Bishofs Zeno von Verona. Christus als wahre und ewige Sonne', Antike und Christentum, vi, 1940 , pp. 4ff. Julian the Apostate calls Helios 'the God of the seven rays', see his Oration V, Hymn to the Mother of Gods, 173D. On stars with a different number of rays symbolising the sun see Cumont (as in n. 33), pp. 207 and $240 \mathrm{ff}$.

48 See Grabar 1968 (as in n. 26).

49 Corpus Vasorum Antiquorum, Italia xlvi, Ceramica etrusca a figure rosse, Museo Nazionale di Antichità di Parma, ed. M. P. Rossignani, Rome 1970, pls 1, 1-2; 2, $1-3$. This vase is considered to be Etruscan. J. D. Beazley (Etruscan Vase-Painting, Oxford 1947, pp. 37-38) thinks that it derives from Attic models of about 420 BC. He 
eclipse) is represented as a clipeus with numerous pointed rays, enclosing the bust of a long-haired young man. Six naked satyrs, their eyes fixed on Helios's face, witness the event. Their admiration, or astonishment at what they see, is conveyed by their poses, gestures and expressions - they are all wide-eyed and open-mouthed. Various elements which appear in the Sinai Transfiguration are present in this scene, which is itself unique in the history of ancient art. The similarity is apparent in the almost symmetrical layout of the composition, in the central figure emitting rays, in the poses and gestures of the witnesses, in their positioning and in the atmosphere created by the miracle. The representations of the sun as a circle with emanating rays or as a star, together with the scene on the Parma vase, constitute a body of comparative material sufficient to conclude that there is a close correlation between the Sinai Transfiguration and the iconography of the sun. ${ }^{50}$ What then is the function of the solar element in all this?

The Transfiguration figures in all three synoptic Gospels. Luke (ix, 29-30) says: 'And as he (Christ) prayed, the fashion of his countenance was altered, and his raiment was white and glistering. And, behold, there talked with him two men, which were Moses and Elias' Mark (ix, 3): 'And his raiment became shining, exceeding white as snow; so as no fuller on earth can white them.' The most important of the three for our purposes is Matthew (xvii, 2): 'And was transfigured before them: and his face did shine as the sun, and his raiment was white as the light.' Nevertheless, even an eloquent comparison of Christ with the sun is not the same as actually calling him the sun. These Gospel passages were commented on repeatedly by Christian writers from the third century onwards, with the sun analogy receiving extended treatment. ${ }^{51}$ Origen in his Commentary on Matthew says:

And when he is transfigured his face shines like the sun so that he may be revealed to the children of light who have put off the works of darkness and put on the armour of light and are no longer children of darkness or night, but have become the sons of day and walk

describes the scene as follows: 'The subject must surely go back to an Attic satyr-play ... A possible plot would be an eclipse of the Sun: dismay and despair of the Satyrs. But the sun blazes out again: the Satyrs dazzled, amazed and delighted ...' See also K. Schauenburg, Helios. Archäologish-mythologische Studien über den antiken Sonnengott, Berlin 1955, pp. 11-15. On the use by medieval artists of motifs taken from Greek vases see R. H. L. Hamann MacLean, 'Antikenstudium in der Kunst der Mittelalters', Marburger Jahrbuch für Kunstwissenschaft, xv, 1949-50, pp. 215ff; on Greek works of art used as models by early Christian and Byzantine artists, see e.g. K. Weitzmann, Greek Mythology in Byzantine Art, 2nd edn, Princeton 1984; idem, 'The Survival of Mythological Representations in Early Christian and Byzantine Art and their Impact on Christian Iconography', Dumbarton Oaks Papers, xiv, 1960 , pp. 45-68; E. Kitzinger, 'The Hellenistic Heritage in Byzantine Art', ibid., xvii, 1963, pp. 97-115; see also D. V. Ainalov, The Hellenistic Origins of Byzantine Art, transl. E. and S. Sobolevitch, ed. C. Mango, New Brunswick 1961, passim.

50 On solar motifs and themes in Christian art see among others: P. E. Schramm, Sphaira, Globus, Reichsapfel. Wanderung und Wandlung eines Herrschaftszeichens, Stuttgart 1958, pp. 36-40; H. Sedlmayr, 'Zeichen der
Sonne' in idem, Epochen und Werke, ii, Vienna 1960, pp. 249-56; P. Verdier, 'La colonne de Colonia Aelia Capitolina et l'imago clipeata du Christ Helios', Cahiers archéologiques, xxiii, 1974, pp. 20-40, esp. 36ff; J. Huskinson, 'Some Pagan Mythological Figures and their Significance in Early Christian Art', Papers of the British School at Rome, xlii, 1974, pp. 68-97, esp. 78-81 and 82-85; H. Schrade, Ikonographie der christlichen Kunst, I, Auferstehung Christi, Berlin 1932, pp. 39-40; Hautecoeur (as in n. 25), passim; Baltrušaitis (as in n. 31), passim; J. Miziolek, Sol Verus. Studies on the Iconography of Christ in the Art of the First Millennium (in Polish with an English synopsis, forthcoming).

51 Early Christian commentaries on the Transfiguration are treated by M. Aubineau, 'Une homélie grecque inédite sur la Transfiguration', Analecta Bollandiana, lxxxy, 1967, pp. 402-27. See also J. A. McGuckin, The Transfiguration of Christ in Scripture and Tradition, New York 1986 (including an anthology of translated patristic texts on the Transfiguration); Joie de la Transfiguration d'après les Pères d'Orient, ed. M. Coune, Bégrolles-enManges 1985. H. Riesenfeld, Jesus transfiguré. L'arrière plan du récit évangelique de la Transfiguration de Notre Seigneur, Copenhagen 1947, is still the best general study of the subject. 
uprightly as in the day. Being revealed to them he will shine on them not only as the sun, but one seen to be the Sun of righteousness (xii, 37). ${ }^{52}$

In his sermon on the Transfiguration, Ephraem Syrus writes about two suns which were seen by the three Disciples on Mount Tabor-the natural sun and the face of Christ; the light radiating from Christ's face, brighter than the light of the natural sun, revealed the magnificence of the divinity of the Transfigured Son of Man. ${ }^{53}$ Whereas Moses's face at Sinai shone with the reflected glory of the Lord, Christ's glory on Tabor was that of his own divinity. Similar words occur in a fifth-century anonymous Latin writer, Pseudo-Leo:

Today in his Transfiguration, he (Christ) wished to make a unified harmony of both Scriptures ... Today the Disciples were able to see two suns upon the mountain; the first was in the firmament and can be seen by all men, but the other shines more splendidly than this and is seen only by the prophets and Disciples: the face of Jesus. This Sun flashes on the mountain and by its power lights up that other which is in the firmament. This is the Sun of justice which shines and blazes: in its blazing it enkindles the faithful, and in its shining it illumines all men. Of this Sun John says: 'That was the true Light, which lighteth every man that cometh into the world.' 54

St Ambrose refers to the Transfigured Christ both as the eternal Sun of righteousness and as the divine Sun, ${ }^{55}$ while St Augustine says: 'He is the Sun foretold by the prophets.' ${ }^{56}$ The recently discovered Sermon for the Feast of the Transfiguration by Anastasius of Sinai postdates the Sinai mosaics by a century. None the less, it is a particularly significant document for their iconography. Anastasius spent many years at the monastery and around 680 was its hegoumenos. ${ }^{57}$ In the sermon he refers to Christ as both the Sun and the Sun of righteousness, the Sun that 'casts down' rays. ${ }^{58}$ Moreover Anastasius, obviously inspired by II Corinthians iii, 7-18,

52 Transl. in McGuckin (as in n. 51), p. 157. For Greek text: Origenes Werke, $\mathrm{x}$, 'Die griechischen christlichen Schriftsteller der ersten drei Jahrhunderte', Leipzig

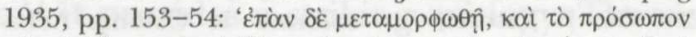

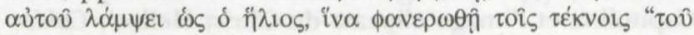

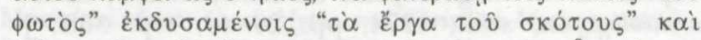

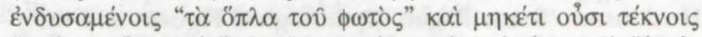

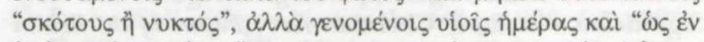

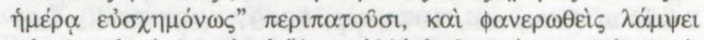

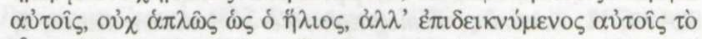

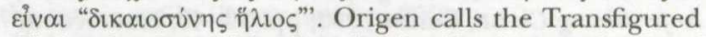
Christ the Sun of justice also in Homilies on the Gospel

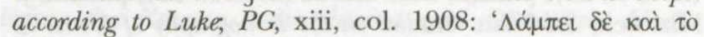

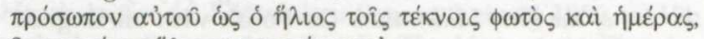

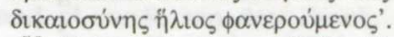

53 Ephraem Syrus, Rede über die Verklärung Christi, Bibliothek der Kirchenväter, xxxvii, Munich 1919, pp. 186-87. Aubineau (as in n. 51), p. 403 points out that this text was written by an unknown Christian exegete in the fifth-century-Psuedo-Ephraem. See also Coune (as in n. 51), pp. 92, 101.

54 Sermo xx, De Transfiguratione Domini, ch. 2; PL, liv, col. 521. Transl. in McGuckin (as in n. 51), p. 286.

55 Expositio Evangelii Secundum Lucam vii, 14; CSEL, xxxii, 4, p. 288: 'Quis est iste fullo, nisi qui indumenta nostri intellectus indumenta virtutum ablutis maculis corporalibus soli solet offerre divino.' A description of the Transfigured Christ as Sol aeternus is found in Ambrose, Enarratio in Psalmum xlv; CSEL, lxiv, pp. 330f. 56 Sermo lxxviii; PL, xxxviii, col. 491: 'Moyses et Elias, id est, Lex et Prophetae quid valent nisi cum Domino colloquantur? Nisi Domino perhibeant testimonium, quis leget Legem? quis Prophetas? Videte quam breviter hoc Apostolus ait: Per Legem enim cognitio peccati: nunc autem sine Lege, justitia Dei manifestata est, ecce Sol: testificata a Lege et Prophetis ecce splendor.'

57 On this homily of. Guillou (as in n. 4), pp. 217ff, esp. pp. 235ff; on pp. $237-57$ is the full text on this homily in Greek. Cf. Sevčenko (as in n. 2), pp. 260ff; see also Coune (as in n. 51), pp. 152ff.

58 Guillou (as in n. 4), p. 237, 8-10: " $\Omega \varsigma$ фоßєро̀ ó

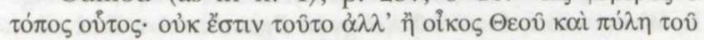

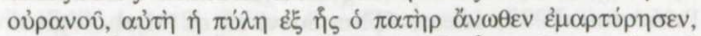

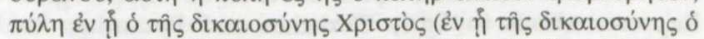

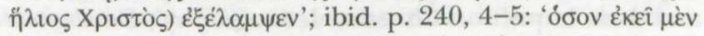

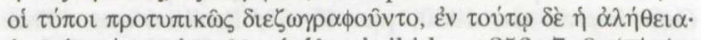

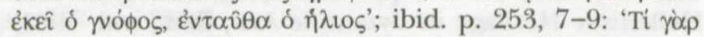

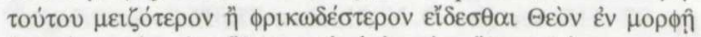

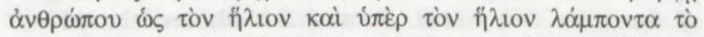

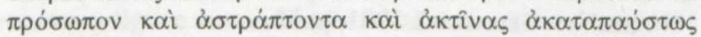
$\phi \varepsilon \gamma \gamma \circ \beta 0 \lambda o v ̂ v \tau \alpha ;$ ' Basil of Seleucia in Sermo xl also writes on the Transfigured Christ who 'cast down' rays: $P G$, lxxxy, col. 458. 
speaks (as did before him Irenaeus of Lyons, John II, Bishop of Jerusalem, and the Pseudo-Leo) of the theophany on Mount Tabor as being the fulfilment of the Lord's glory on Sinai. ${ }^{59}$

In all the commentaries so far mentioned, whether Greek, Latin or Syriac, solar definitions of Christ serve a double purpose. On the one hand they underline the divine nature of Christ, and on the other they contrast the true Light that emanates from Christ with the light of the sun 'qui adoratur a paganis et Manichaeis' ${ }^{60}$ If it is borne in mind that the divinity of Christ is given effect on Mount Tabor by way of an exegesis of the Old Testament event on Mount Sinai, the 'solarity' of Christ becomes significant in terms both of demonstratio and of praeparatio evangelica: what Moses had veiled, and what the pagans had been deflected from by worshipping the natural sun, stands revealed in the glory of the Transfiguration. ${ }^{61}$

But are the rays in the Sinai Transfiguration sufficient grounds for interpreting the portrayal of Christ as the spiritual Sun of righteousness? To answer this question let us make the following comparison. An identical motif of rays appears in scenes depicting the Harrowing of Hell. ${ }^{62}$ The earliest known example, in which the rays are symmetrically arranged as in the Sinai Transfiguration, is the mosaic chapel of $\mathrm{S}$. Zeno at S. Prassede in Rome dating from the first quarter of the ninth century

59 For Anastasius's texts, see Guillou (as in n. 4), pp.

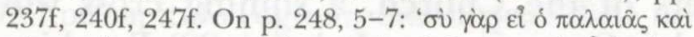

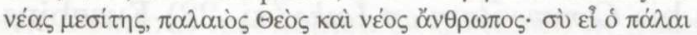

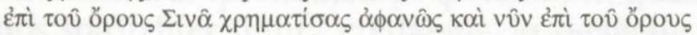

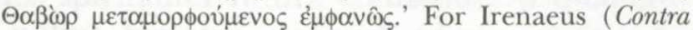
haereses, iv, 20, 9) see $P G$, vii, col. 1038. For John ii (Homily on the Feast of the Transfiguration) see Coune (as in n. 51), pp. 66-74, esp. 69-70. For the Pseudo-Leo text (Sermo xx, 4), PL, liv, col. 522: 'In hac siquidem die, quod suo famulo promisit Moysi, fideliter per Filium Pater complevit'; see also St Jerome, Commentarius in Epist. ii ad. Cor:: PL, xxx, cols 778-80.

60 These words occur in St Augustine's Enarratio in Ps. $\mathrm{xxv}, 3$ : CCSL, xxxviii, p. 143. As is well known, the pagan cult of the Sun reached its peak in the 3rd century and at the beginning of the 4th, but even in St Augustine's and Leo the Great's day there seemed to be a fairly large number of sun-worshippers, as the repeated warnings against them testify; for Augustine e.g. Sermo cxc, vii, 1 (PL, xxxviii, col. 1007) and Enarrationes in Psalmos x, 3; lxxx, 14; xciii, 4; ciii, 19-23; cxlii, 3; cxlviii, 16; cf. also xcvi, 18 (CCSL, xxxviii-xl). Cf. also Theodoret of Cyrus, Hellenikon therapeutike pathematon, iii, 6-13 (Théodoret de Cyr, Thérapeutique des maladies helléniques, ed. P. Canivet, Paris 1958, pp. 172ff). For Leo the Great see e.g. his famous Sermo xxvii, CCSL, cxxxviii, p. 135. Traces of this cult may have survived into the sixth century. Caesarius of Arles, following strictly Augustine's Enarr. in Ps. xxy, 3, writes: 'Eice illam de corde, antequam occidat lux ista visibilis, ne te deserat lux illa invisibilis. Sed et aliter melius intellegitur, quia noster sol iustitiae et veritatis Christus: non iste sol qui adoratur a paganis et Manichaeis, et videtur etiam a peccatoribus, sed ille alius cuius veritate anima humana inlustratur, ad quem gaudent angeli' (Sermo, clxxx, 2: $C C S L$, civ, p. 731). For the persistence of the cult of the
Sun in late antiquity and in christianised areas see among others: M. P. Nilsson, Geschichte der griechischen Religion, ii, Munich 1961, pp. 509-19; idem, 'Die Religion in den griechischen Zauberpapyri', K. Humanistika Vetenskapsamfundets $i$ Lund Årsberättelse, Lund 1947-48, pp. 77-79; H. Seyrig, 'Le culte du Soleil en Syrie à l'époque romaine', Syria, xlviii, 1972, pp. 337-73; G. H. Halsberghe, The Cult of Sol Invictus, Études (as in n. 44), xxiii, Leiden 1972; J. Tubach, Im Schatten des Sonnengottes. Der Sonnenkult in Edessa, Harran und Hatra aus Vorabend der christlichen Mission, Wiesbaden 1986. For philosophical background see F. Altheim, 'Porphyrios Schrift uber den Sonnengott', in Aus Spätantike und Christentum, Tübingen 1951, pp. 1-56; J. Flamant, Macrobe et le néoplatonisme latin à la fin du IVe siècle, Études (as above), lviii, Leiden 1977, ch. xiv, pp. 652ff; H. D. Saffrey, 'La dévotion de Proclus au Soleil', in Philosophies non chrétiennes et christianisme, Brussels 1984, pp. 73-86. On the assimilation of the cult of the Sun by Christianity and Christ as Sol justitiae, verus, novus, aeternus, salutis, etc. e.g. H. Usener, 'Sol Invictus', Rheinisches Museum, lx, 1905, pp. 465-91; F. J. Dölger, Die Sonne der Gerechtigkeit und der Schwarze, Münster i. W. 1918, esp. pp. 100-10; idem 1925 (as in n. 37), and 1940 (as in n. 47), pp. 1-56; Rahner (as in n. 42), pp. 89ff; E. H. Kantorowicz, 'Oriens Augusti-Lever du Roi', Dumbarton Oaks Papers, xvii, 1963, pp. 135ff; Tubach (as above), pp. 83-114.

61 The concept of Christ as the Sun in the Transfiguration was still very popular in the Middle Ages, see Homilies on the Feast of the Transfiguration by John of Damascus: $P G$, xcvii, cols 932ff; Andrew of Crete: $P G$, xcvii, cols 932ff; Peter the Venerable: $P L$, clxxxix, cols 953ff; Gregory Palamas: $P G$, cli, cols $424 \mathrm{ff}$.

62 See Kartsonis (as in n. 19), passim; E. Lucchesi Palli, 'Höllenfahrt Christi', in Kirschbaum (as in n. 8), ii, cols 322-31. 
(Pl. 7a). ${ }^{63}$ The lower part of the mosaic is damaged, but enough remains to justify the inference that originally the scene depicted Christ encircled by eight rays; six are extant. A well-preserved example of a scene showing eight rays can be found in the mid-eleventh-century rock church of St Barbara in Soganle in Cappadocia (Pl. 5c). ${ }^{64}$ Two texts may be cited: Melito of Sardis calling Christ 'King of Heavens and creation's Captain, the Sun of the rising who appeared both to the dead in Hades and to mortals in the world'; ${ }^{65}$ and Pseudo-Epiphanius referring to him as 'the great Samson, God the Sun who shone in Limbo.' ${ }^{66}$

A Resurrection portrayal may also involve solar elements. A miniature in the Rabbula Gospels shows the Holy Sepulchre as a small chapel with columns, from whose half-open door emanate three rays which strike down the guards (Pl. 8a) - a synecdoche for the rising sun and the risen Christ. ${ }^{67}$

If the Transfiguration 'fulfils' the theophany on Mount Sinai, it anticipates the Parousia at the end of time. ${ }^{68}$ Like the Transfiguration, the Parousia is a phenomenon of supernatural light or glory. ${ }^{69}$ In the Sinai mosaic the reference to the future event is carried by the luminous cross in the axis between Christ and the Lamb. According to the Gospels and the Fathers of the Church, a shining cross will precede Christ at the Second Coming. ${ }^{70}$ In his Commentary on Luke (xi, 28) Eusebius

63 B. Brenk, 'Zum Bildprogramm der Zenokapelle in Rom', Archivo español de arqueologia, xlv-xlvii, 1972-1974, pp. 215-17 and fig. 2; C. Davis-Weyer, 'Die ältesten Darstellungen der Hadesfahrt Christi, das Evangelium Nikodemi und ein Mosaik der Zenokapelle', Roma e l'età carolingia. Atti delle giornate di studio, Rome 1976, pp. 183-94. For a colour reproduction see J. Wilpert and W. N. Schumacher, Die römischen Mosaiken der kirchlichen Bauten vom IV.-XIII. Jahrhundert, Freiburg 1976, fig. 114b. The same arrangement of rays as in the Sinai Transfiguration is in the Anastasis scene in the Chludov Psalter (illustration to Psalm lxxxi) - see Ščepkina (as in n. 47), fol. $82^{v}$. As in the Transfiguration scenes the number of rays varies; see Schiller (as in n. 13), iii, figs 99 and 125.

64 A. Grabar, Byzance. L'art byzantin du moyen âge, Paris 1963, colour reproduction on p. 15; Restle (as in n. 24), iii, fig. 440 .

65 Melito of Sardis, On Pascha and Fragments, transl. S. G. Hall, Oxford 1979, pp. 72-73. See also Dölger 1925 (as in n. 37), pp. 342-45, pp. 336-79 for a collection of texts with commentaries on Christ as the Sun of justice shining in Limbo.

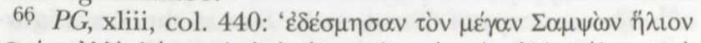

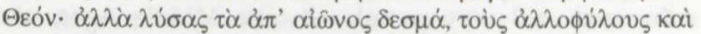

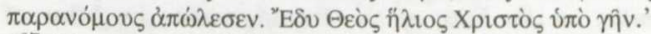

67 Florence, Bibl. Laurenziana, Plut. 1, 56, fol. 13' ${ }^{\mathrm{r}}$. See C. Cecchelli, G. Furlani, M. Salmi, The Rabbula Gospels, facsimile, Olten 1959. For an interpretation see P. Wilhelm, 'Auferstehung Christi', in Kirschbaum (as in n. 8), i, col. 203; Kartsonis (as in n. 19), pp. 21-22 and $71-72$.
68 On eschatological features of the Sinai Metamorphosis see Weitzmann in Forsyth \& Weitzmann (as in $\mathbf{n}$. 1), pp. 14ff; cf. Kitzinger (as in n. 2), p. 98. The Transfiguration as a vision of the Second Coming has been considered by many theologians, patrologists and art historians; see for example Riesenfeld (as in n. 51), pp. 292ff; McGuckin (as in n. 51), pp. 120-22; Nordström (as in n. 19), pp. 130ff; Dinkler (as in n. 6), passim; F. W. Deichmann, Ravenna, Hauptstadt des spätantiken Abendlandes, ii, Wiesbaden 1976, Kommentar, ii, pp. 251-54; Dufrenne (as in n. 6), pp. 185ff; C. Müller, 'Das Apsismosaik von S. Apollinaire in Classe. Eine Strukturanalyse', Römische Quartalschrift, lxxv, 1980, pp. $11-50$.

69 cf. Matthew xxiv, 27. Very often parousiac visions involve solar metaphors, see Epistula Apostolorum, ch. 16; Apocalypse of Peter (Ethiopic text, ch. 1); also St Gregory of Nyssa's Treatise on the titles of the Psalms, ii, 5 (PG, xliv, col. 505) and St Ambrose's Expositio in Lucam, x, 41-43 (CSEL, xxxii, 4, p. 470f).

70 On the luminous cross as a sign of the Second Coming see Dinkler (as in n. 6), pp. 50-87; E. H. Kantorowicz, "The King's Advent" and the Enigmatic Panels in the Doors of Santa Sabina', Art Bulletin, xxvi, 1944, pp. 224ff; J. Engemann, 'Zu den Apsis Tituli des Paulinus von Nola', Jahrbuch für Antike und Christentum, xvii, 1974, pp. 21-46, esp. pp. 30-31. C. Vogel, 'La croix eschatologique' in Noël-Epiphanie. Retour du Christ, Paris 1967, pp. 85-108. In Weitzmann's opinion (Forsyth \& Weitzmann, as in n. 1, p. 14): 'the golden cross in the clipeus, set against three concentric strips, symbolising 
of Caesarea says:

... in the fulfilment of the age, when the Lord comes with the Father's glory then it will not only be Moses and Elijah who shall attend him, and it will not only be three Disciples who are there, but all the prophets and patriarchs and just men. And it will not be up a high mountain but to heaven itself that he will lead the worthy by his godhead. ${ }^{71}$

The eschatological aspect of the Transfiguration seems to be confirmed by the presence of the prophets and perhaps also David in the apse mosaic. In the Acts of the Apostles (iii, 19-24), it seems to be suggested that all the prophets foretold the Second Coming. According to Origen, ${ }^{72}$ St Basil the Great ${ }^{73}$ and St Augustine, ${ }^{74}$ the Second Coming is also foretold in the Psalms. Some of these prophecies, and comments on them, may have been used as literary sources for the Sinai mosaics. There is also the much interpreted passage in Malachi (iv, 2-5), which brings together Horeb-Sinai, Moses and Elijah, the Sun of righteousness and the 'fulfilment of the age'; 75 and Isaiah (lx, 19-20):

... The Lord shall be unto thee an everlasting light. And thy God thy glory. Thy sun shall no more go down ... for the Lord shall be thine everlasting light and the days of thy mourning shall be ended.

In his commentary on this text St Jerome establishes a relationship between the brightness of the light of the Lord and Malachi's Sun of righteousness: ${ }^{76}$

Et hoc capitulo cogimur omnia quae dicta sunt et dicenda, ad ultimum referre tempus ... Et erit Dominus ipse lumen perpetuum, ut quae $\chi \uparrow \lambda \iota \alpha \sigma \tau \alpha i$ carnaliter asserunt esse complenda, nos spiritaliter futura credamus, in qualitate promissionum, non in tempore discrepantes. Quibus breviter respondendum est, quod pseudo-prophetis et peccatoribus sol occidit meridie, et e contrario timentibus Dominum oritur sol iustitiae. ${ }^{77}$

The Sinai representation of Christ may be compared with images of Christ at the Second Coming in the Roman churches of S. Paolo fuori le mura (Pl. 6a) and SS. Cosma e Damiano (Pl. 6b), where the solar meaning is well established. On the wall of the triumphal arch in S. Paolo, Christus-Helios in a clipeus, from which issue

the Trinity, alludes to the divine nature of Christ'. This cross could also allude to the Passion; for this problem see Deichmann (as in n. 68), Kommentar, ii, pp. $246 \mathrm{ff}$.

71 Transl. in McGuckin (as in n. 51), p. 166. For Greek text: $P G$, xxiv, col. 549. See also John Chrysostom, In Matthaeum Homilia lvi: $P G$, lviii, cols 554f. On this homily as the literary source for the Sinai mosaic see Weitzmann in Forsyth \& Weitzmann (as in n. 1), p. 14. There are many other similar commentaries in patristic literature e.g. Gregory of Nazianzus, Oratio xxix, 19: $P G$, xxxvi, col. 100; John Chrysostom, Ad Theodorum lapsum i, 11: $P G$, xlvii, cols 291ff; Theodoret of Cyrus, Epistle 145: $P G$, lxxxiii, cols $1384 \mathrm{f}$.

72 Contra Celsum, i, 56: Origenes Werke, i, Leipzig 1899, p. 107.

73 Homilia in Psalmum xliv, 5: PG, xxix, col. 44. English transl. in McGuckin (as in n. 51), p. 169: 'The Disciples knew His beauty when he privately explained the parables to them; but Peter and the Sons of Thunder saw his beauty on the sun, and they were found worthy to see with their eyes the preliminaries of his glorious advent.'

74 De civitate Dei, xx, 24: CCSL, xlviii, pp. 745-46.

75 cf. Jerome, Commentary on Malachi iv, 1-3: CCSL, Ixxvi A, pp. 939-42-here the theophany on Mount Tabor is also considered. See also De civitate Dei, xviii, 35, 1-3 and $\mathrm{xx}, 27$.

76 See also Jerome's commentaries on other prophets e.g. In Hiezechielem iii, x, 1ff and xi, 1: CCSL. lxxv, pp. 111-17; In Danielem ii, vii, 1ff. esp. 9b: CCSL, lxxv, A, pp. 837ff; In Osee ii, vi, 1-3: CCSL, lxxxvi, pp. 62-64. Cf. also the so-called Canticle of Habakkuk (Habakkuk iii, 3-4) describing the day of Jahve where Paran and Teman (i.e. Sinai) are mentioned and Jerome's commentary on it: CCSL, lxxvi a, p. 624; Ambrose, Exp. in Lucam, x, 41-43 (CSEL, xxxii, 4, p. 470) and where Zacharias's prophecy on Oriens is mentioned in an eschatological context.

77 Jerome, Commentary on Isaiah xvii, 1x, 19-20: CCSL, Ixxiii A, p. 704. 
nine rays, is surrounded by symbols of the Evangelists and the Elders of the Apocalypse. ${ }^{78}$ In the apse of SS. Cosma e Damiano a full length figure of ChristOriens clothed in a golden garment appears among the apostles and saints, erect on clouds brightened by the dawn, his right hand raised with open palm. ${ }^{79}$ Although these representations of Christ use different iconographic formulae, they are all based on the premise that Christ is the spiritual Sun. Of particular relevance is the image in SS. Cosma e Damiano, because it was executed in the reign of Justinian. Two further examples may be cited: the mosaic in the apse of Hosios David in Thessalonica (Pl. 6c) ${ }^{80}$ and the illustration to Psalms $x l i x / 1$ in the Chludov Psalter (Pl. 8c) probably based on an early Christian model. ${ }^{81}$

The Hosios David mosaic shows a young Christ within a round mandorla, seated on the arc of a rainbow with his right hand raised and his left holding an open scroll inscribed with a paraphrase of Isaiah (xxv, 9). The figure of Christ is set against a shining disc emitting alternately wider and narrower rays of light. From behind the mandorla emerge the symbols of the Evangelists. It is the hill beneath, with the four rivers of Paradise flowing from it, that is the relevant element in the composition. The theophany is witnessed by two prophets, one on each side of Christ. Some scholars believe them to be Habakkuk and Ezekiel, whereas others suggest Isaiah or Ezekiel and St John the Evangelist. ${ }^{82}$ It is probably right to suppose that it is a 'synthetic' representation, combining the Old Testament with

78 For solar symbolism of the representation of Christ on the triumphal arch in S. Paolo fuori le mura, see J. Bolten, Die imago clipeata, Paderborn 1937, p. 49; H. Belting, 'I mosaici dell'aula leonina come testimonianza della prima "renovatio" nell'arte medievale di Roma', in Roma e l'età carolingia (as in n. 63), p. 181 n. 57; Hautecoeur (as in n. 25), p. 192 and n. 9. For a detailed study see J. Miziołek, 'Secundus Adventus. Chrystus jako prawdziwe słońce w sztuce pierwszego tysiaclecia (Christ as the True Sun in the Art of the First Millennium)', Biuletyn Historii Sztuki, xlix, 1987, pp. 3-34. Yves Christe is of the opinion that the representations of Christ adored by Four and Twenty Elders cannot be considered as the Secundus Adventus but as '... une image de la gloire de Dieu et de l'Eglise dans son palais-temple céleste ... après la mort et la Résurrection, acte d'investiture qui établit un règne nouveau et fonde par la même occasion le Règne du Christ et de l'Eglise'; see Y. Christe, 'Apocalypse et interprétation iconographique: Quelques remarques liminiaires sur les images du Règne de Dieu et de l'Eglise à l'époque paléochrétienne', Byzantinische Zeitschrift, lxvii, 1974, pp. 92-93; see also idem, La vision de Matthieu (Matth. $X X I V-X X V)$. Origines et développement d'une image de la Seconde Parousie, Paris 1973, pp. 27 and 66f; idem, 'Les représentations médiévales d'Ap. IV(V) en visions de Seconde Parousie. Origines, textes et contexte', Cahiers archéologiques, xxiii, 1974, pp. 61-72. The Homage of the Elders appears also in Ap. xi, 16 and xix, 4 where the eschatological context seems to be evident. It seems that the representations in S. Paolo fuori le mura have to be considered as an image of the 'synthetic' character, based on different texts, both from Revelation and the Gospels. See J. Engemann, 'Images parousiaques dans l'art paléochrétien', in L'Apocalypse de Jean. Traditions exégétiques et iconographiques, IIIe XIIIe siècles, Geneva 1979, pp. 73-97, esp. 74ff; see also F. van der Meer, Maiestas Domini. Théophanies de l'Apocalypse dans l'art chrétien, Vatican City 1938, p. 91, B. Brenk, Tradition und Neuerung in der christlichen Kunst des ersten Jahrtausends, Vienna 1966, pp. 55, 65 and 73, and Christe himself (1969, as in n. 13), pp. 139ff.

79 C. Davis-Weyer, 'Das Traditio-legis-Bild und seine Nachfolge', Münchner Jahrbuch der bildenden Kunst, xii, 1961 , pp. 7-45, esp. 18ff. See also Y. Christe, 'Apocalypse et "Traditio legis"', Römische Quartalschrift, lxxi, 1976, pp. 42-55.

80 Grabar 1968 (as in n. 26), figs 117 and 280. For a colour reproduction see M. Hirmer \& W. F. Volbach, Early Christian Art, London 1961, figs 134 and 135; on its date see p. 337. For the date see also Kitzinger (as in $\mathrm{n}$. 2), ch. iii, n. 41; Deichmann (as in n. 68), Kommentar, iii, p. 310 .

81 Moscow Historical Museum, MS gr. 129, fol. 48v; see Ščepkina (as in n. 47). The fact that this kind of representation may go back to very early times is suggested by Kantorowicz (as in n. 60), p. 145. Similar representations can also be found e.g. in the London Psalter dating from 1066 in the British Library (fol. $61^{\mathrm{v}}$ ); see S. der Nersessian, Lillustration des psautiers grecs du Moyen Âge. 2. Londres, Add. 19. 352, Paris 1970, pl. 32 , fig. 99 .

82 See F. Hoddinott, Early Byzantine Churches in Macedonia and Southern Serbia, London 1963, pp. 173-77, where previous interpretations are also considered; see also F. Gerke, 'Il mosaico apsidale di Hosios David di Salonicco', Corsi di cultura sull'arte ravennate $e$ bizantina, xi, 1964, pp. 179-99. 
Revelation. ${ }^{83}$ One may surmise that the representation of Christ against a radiant disc carries a reference to biblical texts and commentaries which contain solar metaphors and speak of God as the spiritual Sun, for example, Isaiah (lx, 19-21), Malachi (iv, 2) and St Jerome's commentaries on these passages; ${ }^{84}$ perhaps also Revelation (i, 16): '... And his countenance was as the sun shineth in his strength.' 85

In the Chludov Psalter (Pl. 8c) it is the prophet Habakkuk who witnesses the theophany. He is seen together with David, paying homage to the clipeus which bears the bust of a bearded Christ. The group is framed, above and below, by the rising and setting sun shown respectively as a youth driving a quadriga, and as a head, encircled with rays, disappearing behind a hill. It has been argued persuasively that some portrayals of Christ in a clipeus in Byzantine psalters represent Christus-Helios. ${ }^{86}$ The miniature in the Chludov Psalter is a case in point; but does it represent the First or the Second Coming? The verses of Psalms xlix/1 (1-3) which the miniature illustrates offer no pointers, but patristic commentaries suggest the latter, for instance John Chrysostom:

... Matthew makes clear how manifestly Christ's second coming will proclaim itself. For it needs no-one to herald it. His coming by and of itself will proclaim itself. David also pointed this out when he said: 'God in full manifestation will come'. ${ }^{87}$

*

It has been contended that the Lamb of God which appears on the triumphal arch in Sinai represents the Lamb of the Apocalypse. ${ }^{88}$ This seems very likely as two contemporary representations of the Transfiguration, in the Chiesa del Salvatore (Stefania) in Naples, ${ }^{89}$ and in the Euphrasian basilica in Poreč (Parenzo), ${ }^{90}$ include references to the Apocalypse; the former is known to have represented the Elders doing homage to the figure on the throne (Revelation iv, 10-11; xi, 16; xix, 4) and

83 J. Snyder, "The Meaning of the "Majestas Domini" in Hosios David', Byzantion, xxxvii, 1967, pp. 143-52. See also M. Werner 'On the Origin of Anthropomorphic Evangelist Symbols: The Early Christian Background', Studies in Iconography, x, 1984-86, pp. 15-16.

84 For Jerome's commentaries on Isaiah and Malachi see above, nn. 75 and 77 ; see also other commentaries indicated in $\mathrm{n} .76$.

85 The Apocalyptic Christ is already called the 'true Sun' by Origen: see C. Diobouniotis and A. Harnack, Der Scholien-Kommentar des Origenes zur Apokalypse Johannis, Leipzig 1911, pp. 24-25. See also Dölger 1918 (as in n. 60), p. 102 n. 2. In this case the description 'true Sun' is linked rather with Revelation i, 20. For commentaries on Revelation i, 16, see e.g. PseudoAugustine, Expositio in Apocalipsin b. Joannis, Homilia vii: $P L$, xxxv, col. 2430; Andreas of Caesarea, Commentarius in Apocalypsin ii: $P G$, cvi, col. 229. Cf. Christe (as in n. 79), pp. 42-55.

86 Kantorowicz (as in n. 60), figs $31 \mathrm{a}-33$ and pp. 145-48.

87 John Chrysostom, Demonstrations against the Pagans that Christ is God, viii, 2, in Saint John Apologist, transl.
P. W. Harkins, The Fathers of the Church, lxxiii, Washington D.C., 1985, pp. 219ff; see also idem, Ad Theodorum lapsum I. 12: PG, 47, col. 393; St Augustine, De civitate Dei, $\mathrm{xx}, 24$. In examples considered by Kantorowicz (as in n. 60), Christ is depicted without a beard-as Emmanuel.

88 See Dinkler (as in n. 6), p. 28; Weitzmann (as in n. 2), p. 401. See also Ihm (as in n. 2), p. 196; Dufrenne (as in n. 6), p. 204. For a criticism of this interpretation see de' Maffei (as in n. 9), p. 194.

$89 \mathrm{Ihm}$ (as in n. 2), pp. 70 and 176-77; Bovini (as in n. 16), pp. 27-30.

90 O. Malajoli (as in n. 17), p. 33; Maksimovič (as in n. 17), pp. 247ff; Beckwith (as in n. 23), pp. 121-22. The Transfiguration is on the eastern façade, the Apocalyptic vision on the west. These mosaics are very badly preserved. Apocalyptic features can also be found in representations of the Transfiguration in the apse of the church of S. Apollinaire in Classe in Ravenna. By the arms of the cross, which represents Christ, there are the letters $A$ and $\Omega$ (Ap. i, 8 and xxi, 6) -see Dinkler (as in n. 6), p. 68; Deichmann (as in n. 68), Kommentar, ii, pp. $255 f$. 
the latter shows Christ with the twelve Apostles and the Apocalyptic candelabra (Revelation i, 12 and iv, 5). Assuming that the Sinai mosaic carries a reference to the Apocalypse, one may also suppose that the medallion bust of David is related to what Christ says of himself in Revelation (xxii, 16): 'I am the root and the offspring of David and the bright and morning star.' As suggested earlier, the rays which emanate from the Sinai Christ could be reminiscent of a star. The verse in Revelation echoes Numbers (xxiv, 17) ('star out of Jacob'), and perhaps other biblical star references, and is related to II Peter i, 18-19, which speaks of the day star in connection with the Transfiguration: ${ }^{91}$

And this voice which came from heaven we heard, when we were with him (Christ) in the holy mount. We have also a more sure word of prophecy; whereunto ye do well that ye take heed, as unto a light that shineth in a dark place, until the day dawn, and the day star arise in your hearts.

Although one cannot be sure exactly which 'word of prophecy' is intended, the verses quoted from the Apocalypse and II Peter seem to suggest that the Sinai Transfiguration could also represent the prophecy which foretells the fulfilment of the glory of the Son of David, the Messiah. ${ }^{92}$ Again we are close to the idea of Christ as the true Light and perhaps close to the idea of the true Sun. Two Syriac authorities may be cited: Ephraem in the Diatessaron links the star of Jacob with the Sun of justice and the star of the Magi with Oriens (ex alto) (Luke i, 78); ${ }^{93}$ in the De coelesti hierarchia, Pseudo-Dionysius the Areopagite writes that the divinity is concealed beneath subtle 'forms'-sometimes it may be the Sun of righteousness, sometimes the day star rising in the hearts of the faithful, and it could also be the spiritual light whose rays embrace us. ${ }^{94}$

91 Biblical star references have been studied excellently by J. Daniélou, 'The Star of Jacob', in idem, Primitive Christian Symbols, transl. D. Attwater, London 1964, pp. 102-23; see also idem, Théologie du judéochristianisme, Paris 1958, pp. 237-47. For patristic commentaries on the 'morning star', see Dölger 1940 (as in n. 47), pp. 18-21 and 31-36.

92 Daniélou 1964 (as in n. 91), pp. 109-10. In the second half of the sixth century in his Commentary on Revelation (xxii, 16) Bishop Andreas of Caesarea wrote: '... Christ "is the bright and morning star." Just as he rose for us on the morning after his three days of death; even so, after the term of this present life, in the morning hour of the general resurrection he will reveal himself gloriously to all his saints, surely bringing in a day that will have no end'; see $P G$, cvi, cols 449-51. It may be of interest to note that the pagan god Radu was worshipped in the Sinai region under the guise of the morning star. Also Isthar was worshipped under the same figure as the goddess of victory. These cults were still alive in the fifth century. Hence the concept of Christ as the rising day star could have been used to assimilate these cults. For the pagan worship of the morning star on Mount Sinai see H. Skrobucha, Sinai, transl. G. Hunt, London 1966, p. 4.

93 Ephraem Syrus, Commentaire de l'Évangile concordant ou Diatessaron, ed. and transl. L. Leloir, Paris 1966, pp. $63 \mathrm{f}$, and $318 \mathrm{f}$. It is worth quoting in this context a passage from the Eastern liturgy for Christmas, which though referring not to the Transfiguration but to the Nativity, gives an interesting example of the star-sun symbolism: 'Thy birth, Christ our God, has risen for the universe as a light of spiritual knowledge; for through thy birth the star-worshippers have learned from the Star to prostrate themselves before thee as before the Sun of righteousness and to recognise thee as the Sunrise from on high', cited from Kantorowicz (as in n. $60)$, p. 141. Cf. also Gregory of Nazianzus (Oratio xl, 5-6) who writes beautifully about 'the mystery of Light' in which Moses on Sinai, Elijah, the 'Beauty of the star', the Transfiguration and other visions are mentioned; see $P G$, xxxvi, cols $363 \mathrm{ff}$, English translation in McGuckin (as in n. 51), p. 169f. Cf. Cornelius a Lapide, Commentarii in Scripturam Sacram, x, Lyons 1865, pp. 757-65, esp. 761ff.-here material on II Peter i, 19, Revelation xxii, 16 and Sol justitiae is assembled.

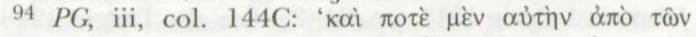

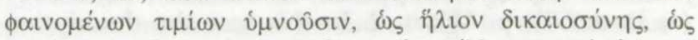

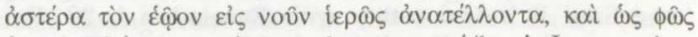

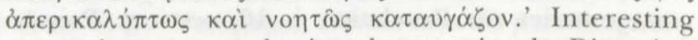
comparisons occur also in other treatises by Dionysius; see De divinis nominibus, i, 6 and iv, 4; in this latter case the sun is called the shining star, and Dionysius compares the sun with God's goodness. It is worth adding that Philo in De opificio mundi, xxxi, calls the intelligible light, created by, and an image of, the Logos, a supercelestial star; see Philo, ed. F. H. Colson, i, London 1929, p. 24. 
It was the opinion of early Christian writers that the image of the Transfigured Christ contained another fundamental truth which concerns the resurrection of Christ's followers at the end of time. In his Commentary on Luke, Cyril of Alexandria writes:

But in the time of resurrection a kind of divine transformation will take place, a change in glory rather than a change in form, and then the body clothed in divine glory will be radiant and the just will shine like the sun in the Kingdom of the Father, as the Saviour said. And so we see the Transfiguration was an example of that glory that is to come, given to the Disciples and revealed in a bodily way to fall under the scope of mortal eyes, even though they could not bear the immensity of the radiance $(v, 29) .95$

Christ's words in Matthew (xiii, 43), 'Then shall the righteous shine forth as the sun ..., were quoted repeatedly in homilies and commentaries in connection with the miracle of the holy mountain (for instance by Gregory of Nazianzus, ${ }^{96}$ John Chrysostom $^{97}$ and Leo the Great). ${ }^{98}$ The vision of the future conveyed in the Transfiguration finds perhaps its most beautiful expression in a passage of PseudoDionysius the Areopagite:

Hereafter, when we have come to be indestructible and immortal and have attained a most blessed and Christ-like lot, 'we shall', as the writings say, 'be always with the Lord' (I Thess. iv, 17) and shall be filled with his visible theophany in the holy contemplations which shall illumine us with the most brilliant splendours as the Disciples were in that most divine Transfiguration ... We shall share in the unity beyond intellect in the unknown and blessed radiations of the rays that are beyond every light. Thus shall we be a more divine imitation of the super-celestial intellects. For as the truth of the writings says, "we shall be equal to the angels and will be sons of God by being sons of the resurrection' (Luke, xx, 36). ${ }^{99}$

It is also worth noting a passsage from the Apocalypse of Peter. Though apocryphal, Sozomen tells us that it was read in Palestinian churches on Good Friday. ${ }^{100}$ The passage is as follows:

And the Lord continued and said, 'Let us go to the mountain and pray.' And we the twelve Disciples went with him and entreated him to show us one of our righteous brethren who had departed from the world, that we might see in what form they are, and taking courage might encourage the men who should hear us. And as we prayed, suddenly there appeared two men standing before the Lord, on whom we were not able to look. For there went forth from their countenance a ray as of the sun, and their raiment was shining such as the eye of

95 Transl. in McGuckin (as in n. 51), p. 181; for Greek text see $P G$, lxxii col. 656. On the Metamorphosis as announcement of the Resurrection glory in patristic exegesis see McGuckin (as in n. 51), pp. 122-25.

96 Sermoxl, 6: $P G$, xxxvi, col. 365.

97 Commentarius in Matthaeum, Homilia lvi, 4: PG, lviii, col. 555. See also Dinkler (as in n. 6), pp. 98, 100.

98 Sermo, li, 3: PL, liv, col. 310. Of great interest are also Jerome's commentaries on II Cor. iii, 18: $P L, \mathrm{xxx}$, col. 780 and Ad. Philip. 3, 20-21: PL, xxx, col. 850. See also Eusebius of Caesarea, Commentary on Luke ix: $P G$, xxiv, col. 549; Theodoret of Cyrus, Epistle 145: PG, Ixxxiii, cols 1384f; and Anastasius of Sinai, see Guillou (as in n. 4),

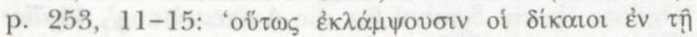

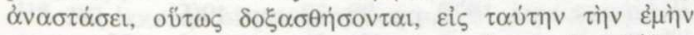

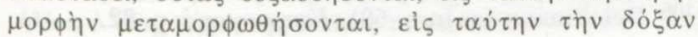

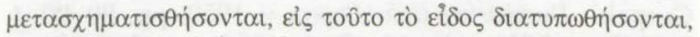

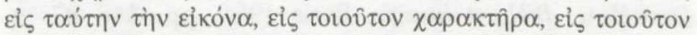

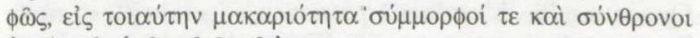

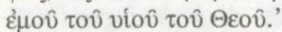

99 De divinis nominibus, i, 4: Pseudo-Dionysius the Areopagite, The Divine Names and Mythical Theology, transl. J. D. Jones, Milwaukee 1980, p. 112. For Greek text see $P G$, iii, col. 592. The Metamorphosis as illuminatio is also written about by Origen (In Genesim, i, 7: $P G$, xii, col. 151f); and St Ambrose in Expositio in Lucam, vii, 12-14: CSEL, xxxii, 4 pp. 287ff. For more examples, see A. J. Vermeulen, The Semantic Development of Gloria in Early Christian Latin, Nijmegen 1956, pp. $160 \mathrm{f}$ and $166 f$.

100 History of the Church, vii, 19: PG, lxvii, cols. 1477ff. 
man never [saw] ... And I approached the Lord and said 'who are these?' He said to me, 'They are your righteous brethren whose form you did desire to see.' And I said to him, 'And where are the righteous, and what is the nature of that world in which these are who possess such glory?' And the Lord showed me a widely extensive place outside this world all gleaming with light, and the air there flooded by the rays of the sun. ${ }^{101}$

If the rays in the Sinai Transfiguration are eight in number, a brief review of the symbolic significance of the number eight may be in order. From the second century onwards this holy number was discussed by both the Greek and Latin Fathers as well as by other Christian authors. ${ }^{102}$ Gregory of Nyssa wrote in the Treatise on the titles of the Psalms that at the end of time the eighth day would come and it would not be brightened by the earthly sun but by the true light, the Sun of righteousness, Christus-Oriens. ${ }^{103}$ Furthermore there is a text which helps us greatly to understand the role of eight rays in the Transfiguration. St Ambrose in his Expositio in Lucam, says:

How was it that Peter, James and John did not taste death but looked upon the glory of the resurrection? For about eight days after these words - 'There are some standing here who shall not taste death' - he took up only these three and led them up the mountain. What then is the meaning of this phrase 'eight days' after these words? It means that the man who hears and believes the word of Christ shall see his glory in the time of the resurrection. For the resurrection is accomplished on the eighth day. This is why so many Psalms bear the title 'On the eighth'. Perhaps it was that he might show us why he had said that the man who loses his life on account of the word of God shall save it since he makes good his promises in the resurrection (vii, 6). ${ }^{104}$

The symbolic eight is present both in architecture-eight columns, eight-sided baptistries with their reference to the Resurrection ${ }^{105}$ - and in figural representation. In the Mausoleum of Galla Placidia in Ravenna eight apostles acclaim a bright cross which symbolises Christ in the centre of the dome. ${ }^{106}$ The cross is

101 E. Hennecke and W. Schneemelcher, New Testament Apocrypha, ii, London 1965, pp. 680-81 (Akhmim fr. 4-14). Also in the Apocalypse of Paul (chaps xii, xx and xxix), the angels, Enoch (the scribe of righteousness) and David have countenances as of the sun; see Hennecke and Schneemelcher (as above), pp. 764, 771-72, 777-78.

102 For this much debated problem see P. A. Underwood, 'The Fountain of Life in Manuscripts of the Gospels', Dumbarton Oaks Papers, v, 1950, pp. 80-90; J. Daniélou, Bible et liturgie, Paris 1951, pp. 346-87; A. Quacquarelli, 'L'ogdoade patristica e i suoi riflessi nella liturgia e nei monumenti', Rivista di Archeologia Cristiana, xlix, 1973, pp. 211-69. See also V. F. Hopper, Medieval Number Symbolism. Its Sources, Meaning and Influence on Thought and Expression, New York 1938, pp. $77 \mathrm{ff}$ and $85 \mathrm{ff}$.

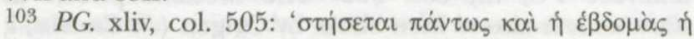

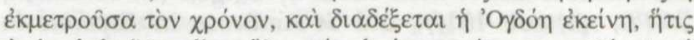

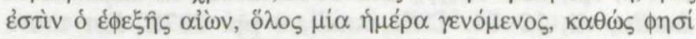

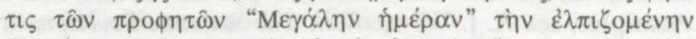

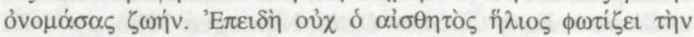

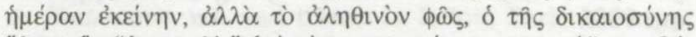

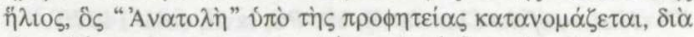

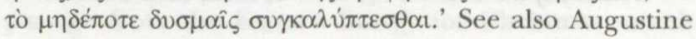

(Sermo cclix: PL, xxxviii, col. 197) for whom the eighth day signifies a new life at the end of time: "After the seventh period of this world is finished, we would come back to a period of happiness.' Many texts explain that the number seven signifies contemporaneity and the number eight life in the future. For some observations on the symbolism of numbers in the Transfiguration see M. Didron, Iconographie chrétienne. Histoire de Dieu, Paris 1843, pp. 117ff; F. Delatte, Études sur la littérature pythagoricienne, Paris 1915, pp. 237-43.

104 Transl. in McGuckin (as in n. 51), pp. 264-65. For the Latin text see CSEL, xxxii, 4, p. 284f. On the symbolism of the number eight in the context of the Transfiguration in the writings of Clement of Alexandria and Origen, see McGuckin (as in n. 51), pp. 122 and 149 .

105 See F. J. Dölger, 'Zur Symbolik des altchristlichen Taufhauses. Das Oktogon und die Symbolik der Achtzahl', Antike und Christentum, iv, 1934, pp. 157-83; R. Krautheimer, "Introduction to an "Iconography" of Medieval Architecture', this Journal, v, 1942, pp. 9-12; Quacquarelli (as in n. 102), pp. 245f. See also R. Staats, 'Ogdoas als ein Symbol fur die Auferstehung', Vigiliae christianae, xxvi, 1972, pp. 29-52, esp. 49ff.

106 Deichmann (as in n. 68), Kommentar, i, p. 82. 
sometimes encircled by eight 'stars' as on the Monza ampullae, a composition some scholars relate to the decoration of the dome of the Holy Sepulchre in Jerusalem. ${ }^{107}$

Finally another doctrinal motif in the Sinai mosaic should be mentioned. Both the inscription (In the Name of [God] the Father, the Son, and the Holy Ghost ...) and the three concentric circles inside the mandorla, each of a different shade of blue, have a Trinitarian connotation. ${ }^{108}$ Comparisons of the Holy Trinity with light, including solar metaphors, occur frequently in the writings of early Christian authors. ${ }^{109}$ For example Gregory of Nazianzus writes that the Holy Trinity is the indivisible deity composed of separate persons, resembling three joined suns which together emit one bright light. ${ }^{110}$ Similar comparisons have been made by Ephraem Syrus and other writers. ${ }^{111}$ Anastasius I, Bishop of Antioch from 559 after he had been a monk in Sinai, identified God the Father with the sun, the Son with its rays, and the Holy Spirit with the warmth that they produce. ${ }^{112}$ This is echoed five centuries later by Theophylact of Achrida. ${ }^{113}$

The image of Christ in a mandorla composed of three concentric ovals emitting eight rays can be related to two other mosaic representations, a contemporary one on the wall of the triumphal arch in S. Vitale in Ravenna (Pl. 7b) ${ }^{114}$ and a mosaic, no longer extant, on the bema of the Dormition church in Nicaea, which dates from the sixth or seventh century (Pl. 8b). ${ }^{115}$ In S. Vitale two angels, flying among the buildings which stand for Jerusalem and Bethlehem, support a medallion depicting a type of cross formed from eight equal arms and inscribed in the centre with the letter 'A'. These arms also seem to be rays of light, initially red, turning first to orange and then to white. The decoration in the Nicaean church is known to have included a medallion depicting a throne set against three concentric blue circles. A book and a cross bearing the dove of the Holy Spirit in the centre were placed on the throne. Four rays of light emanated from the angles of the cross. The arms of the cross turned into rays, thus creating an eight-ray motif, as in S. Vitale. No doubt a Trinitarian reference, perhaps also a solar one, was intended in these

107 See Ihm (as in n. 2), pp. 86-88 and figs 21-22; bibliographical references on p. 88 in nos $38 \mathrm{a}-\mathrm{b}$.

108 For the Trinitarian features of the Sinai Metamorphosis see Weitzmann (as in n. 2), pp. 401ff; idem, in Forsyth \& Weitzmann (as in n. 1), pp. 12ff; de' Maffei (as in n. 9), passim. Ernest J. W. Hawkins is of the opinion that there are four zones of blue in the mandorla.

109 E. Beck, Ephräms Trinitätslehre im Bild von Sonne, Feuer und Wärme, Louvain 1981. See also F. J. Dölger, 'Sonne und Sonnenstrahl als Gleichnis in der Logostheologie des christlichen Altertums', Antike und Christentum, i, 1929, pp. 271-90.

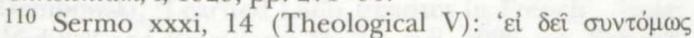

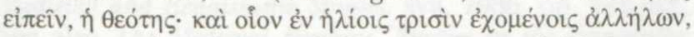

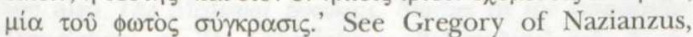
Discours 27-31, ed. P. Gallay, Sources chrétiennes 250, Paris 1978, p. 302. For Gregory's solar metaphors see M. Kertsch, Bildersprache bei Gregor von Nazianz, Grazer theologische Studien, ii, Graz 1980, pp. 150-216.

111 Beck (as in n. 109), passim; see also Tubach (as in n. 60), pp. 100-02.

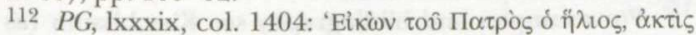

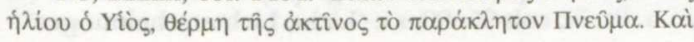

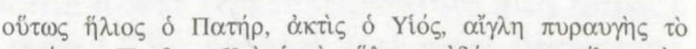

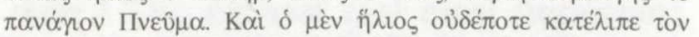

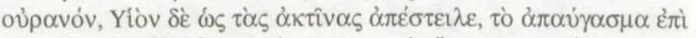

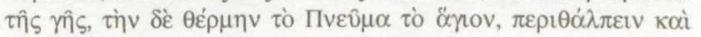

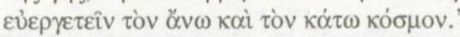

See also Dolger 1929 (as in n. 109), pp. 287-88

113 See $P G$, cxxvi, col. 1209. See also Boethius, De Trinitate, iii, 25f; Boethius, The Theological Tractates, eds H. F. Steward et al., London 1973, pp. $14 \mathrm{f}$.

114 Deichmann (as in n. 68), Kommentar, i, p. 162. For a colour reproduction see R. Farioli, Ravenna romana $e$ bizantina, Bologna 1977, fig. on p. 141. For similar representations see e.g. Ihm (as in n. 2), p. 53 and figs 8 and 9 which depict an eight-pointed star in a clipeus, held by two angels.

115 O. Wulff, Die Koimesis Kirche in Nicäa und ihre Mosaiken, Strassburg 1903, pp. 202ff and pl. i, 1; T. Schmitt, Die Koimesis-Kirche von Nikaia, Berlin 1927, p. 21 and pl. xii; for the date Kitzinger (as in n. 2), pp. 104f. See also V. N. Lasarev, Istorija vizantijskoj živopisi, Moscow 1986, i, p. 37; ii, fig. 22. 
representations. A partially preserved icon in the Sinai monastery dating from the sixth or seventh century seems to supply proof of the Trinitarian aspect in the Sinai image. ${ }^{116}$ This icon was originally a triptych showing on the inside the Virgin flanked by Moses and Elijah, and outside, a symbolic representation of the Transfiguration-the cross in a mandorla composed of three concentric circles, from which emanate four 'bunches' of rays.

There are numerous examples from the first millennium of the theophany with the motif of rays. ${ }^{117}$ In most cases their relationship to solar symbolism is difficult to prove. In the Sinai Transfiguration, however, this relationship seems undeniable owing to the presence of the eight-pointed star-popular symbol of the sun. When applying it to the mosaic, the artist illustrated the essential truths of Revelation. The Transfigured Christ-the Sun of righteousness-placed among Elijah, Moses and other prophets, as well as the Apostles and the Evangelists, is presented as 'the Lord of both the Old and the New Covenants'. The scene looks back to Sinai and anticipates the Resurrection, the Second Coming, and holds the promise to the righteous of a 'change into the same image'.

Polish Academy of Sciences and Letters, Institute of Art History, WarsaW

116 K. Weitzmann, 'An Encaustic Icon with the Prophet Elijah at Mount Sinai', in Mélanges offerts à $K$. Michatowski, Warsaw 1966, pp. 713-23 and pls 1-3; idem, The Monastery of Saint Catherine at Mount Sinai. The
Icons. IFrom the Sixth to the Tenth Century, Princeton 1976, pp. 42-43 and pls xix and lxiv.

117 For examples and bibliography see Kirschbaum (as in n. 8), iii, cols 95-99, s.v. 'Licht, Lichterscheinungen'. 


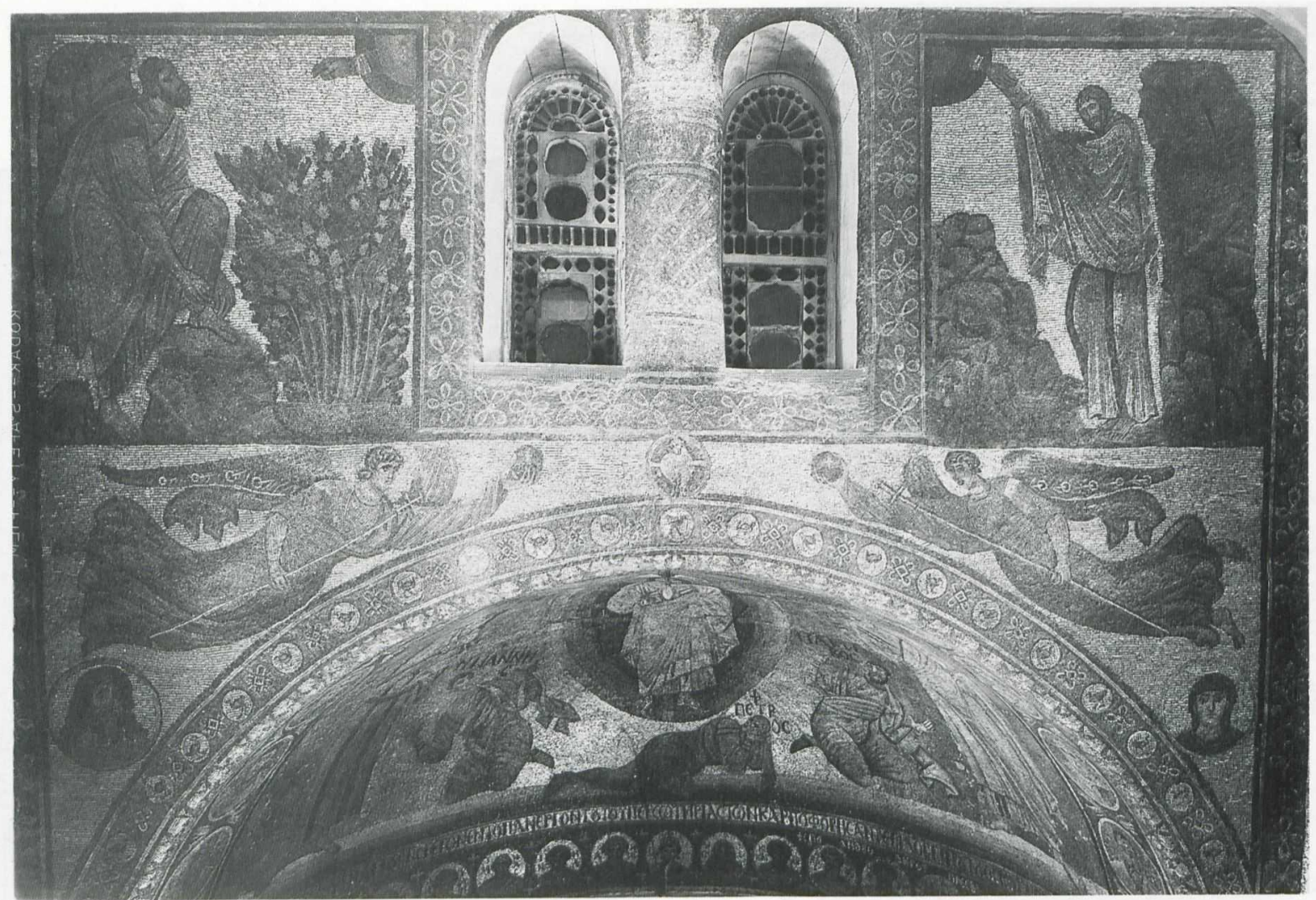

a-Moses on Mount Sinai-Horeb, mosaic above triumphal arch ( $p p .42 f, 50 f)$

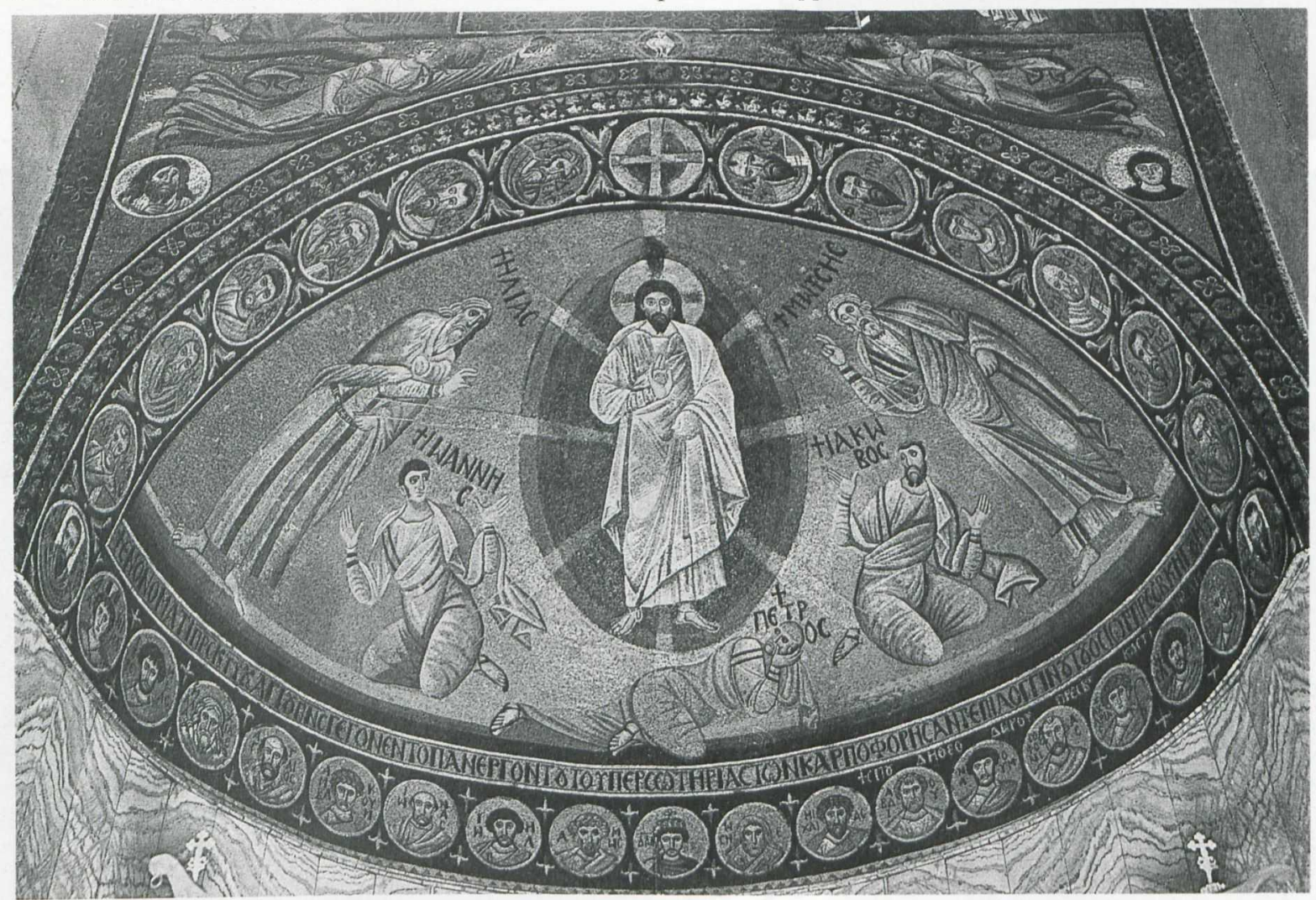

b-Transfiguration, mosaic in apse ( $p p .50 \mathrm{f}$ and passim)

Courtesy Michigan-Princeton-Alexandria Expedition to Mount Sinai a, b: Mount Sinai, Monastery of St Catherine 


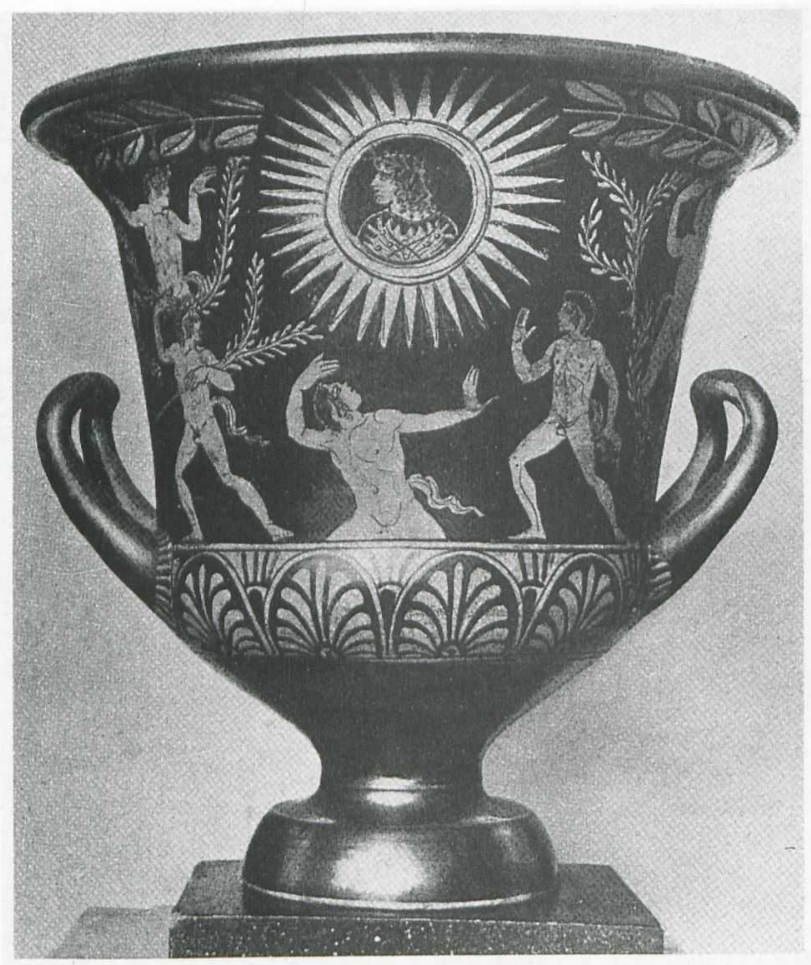

a-Red vase, c. 400 B.C. Parma, Museo Nazionale di Antichità ( $p p .48 f)$

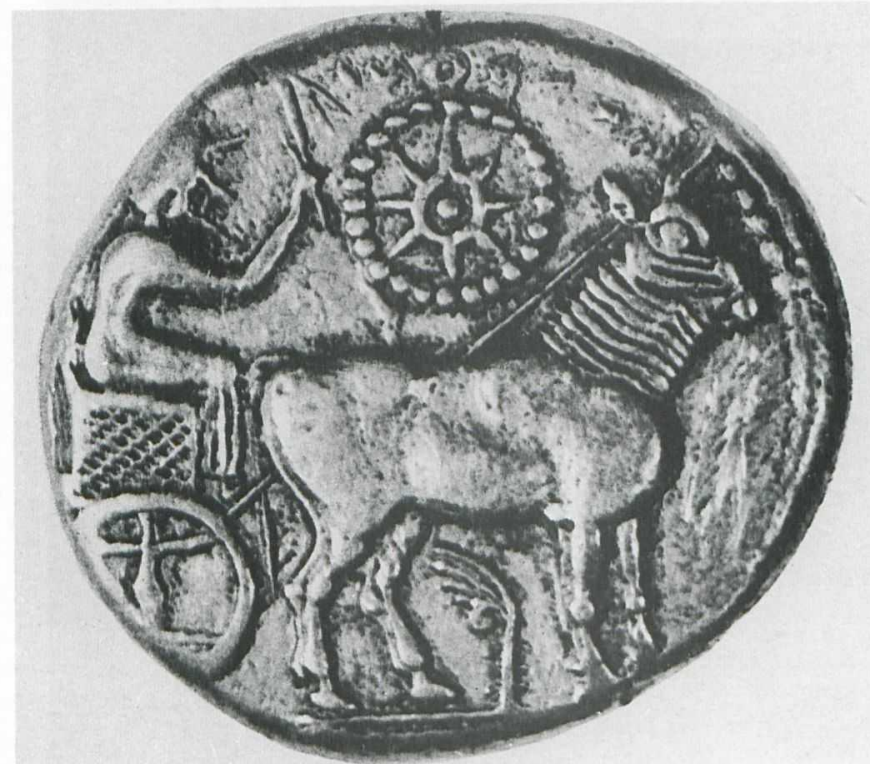

d-Decadrachm, obverse. Sofia, National

Archaeological Museum (p.47)

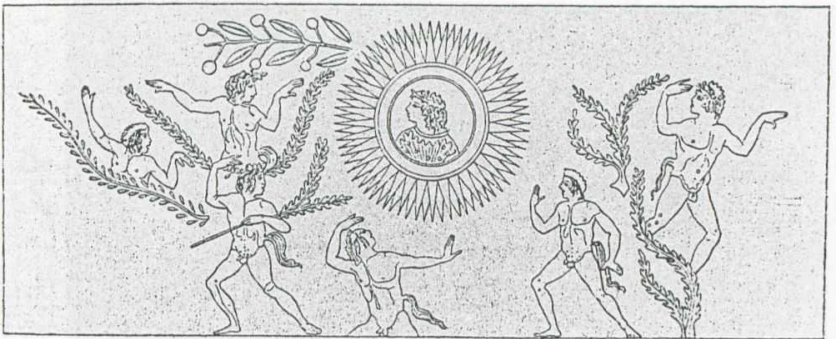

b-Drawing after Pl. 3a ( $p p$. 48f)

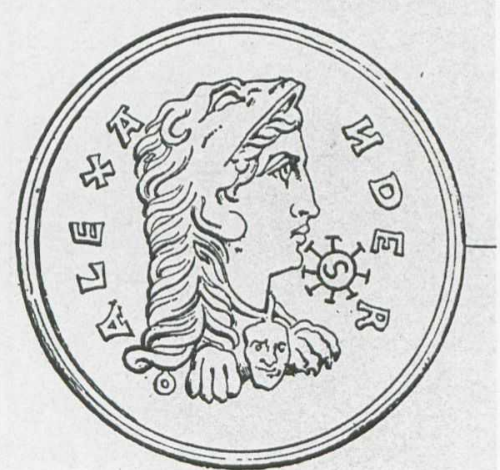

$c$-Medallion (contorniate), obverse. Vatican City, Museo Vaticano (p. 47)

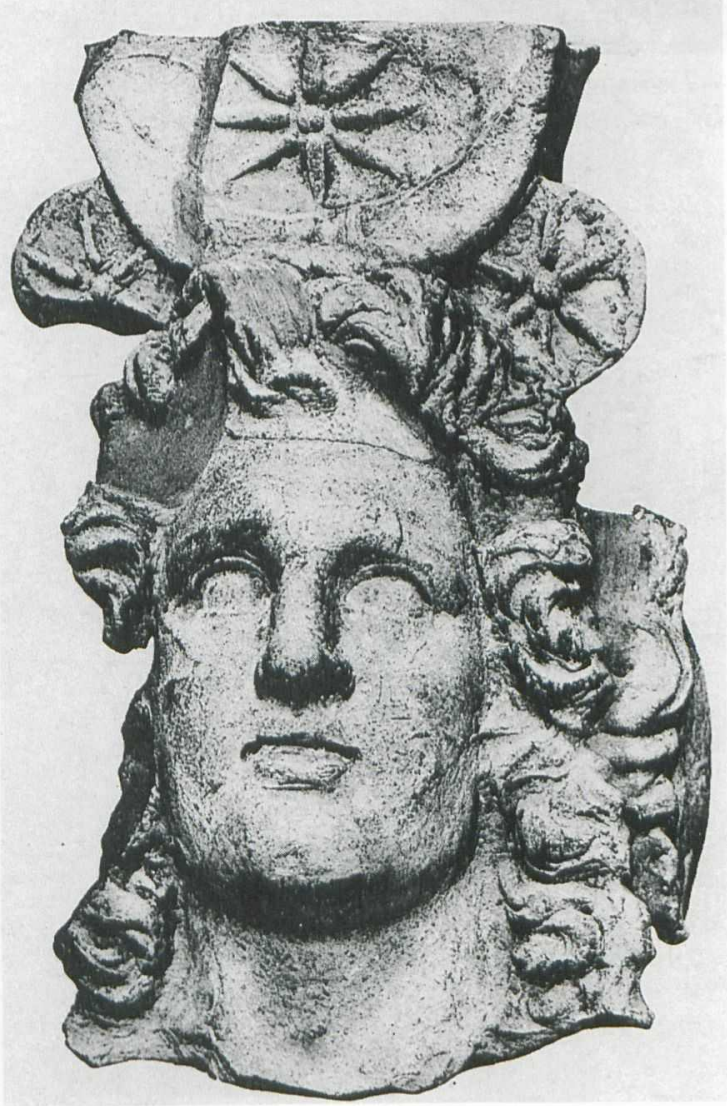

$\mathrm{e}$-Fragment of vase found at Amissus in Pontus. Brussels, Musée du Cinquantenaire ( $p .47)$ 


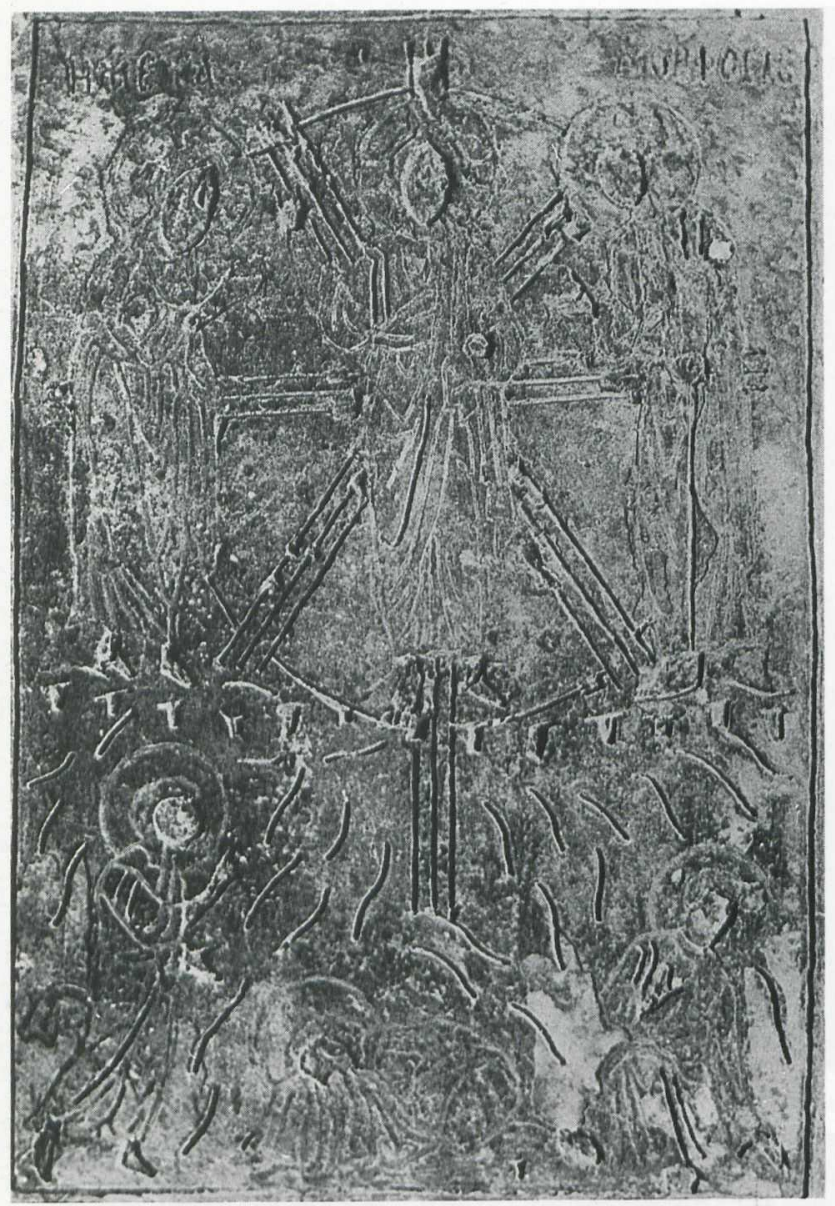

a-Transfiguration. Rome, S. Paolo fuori le mura, bronze door $(p .45)$

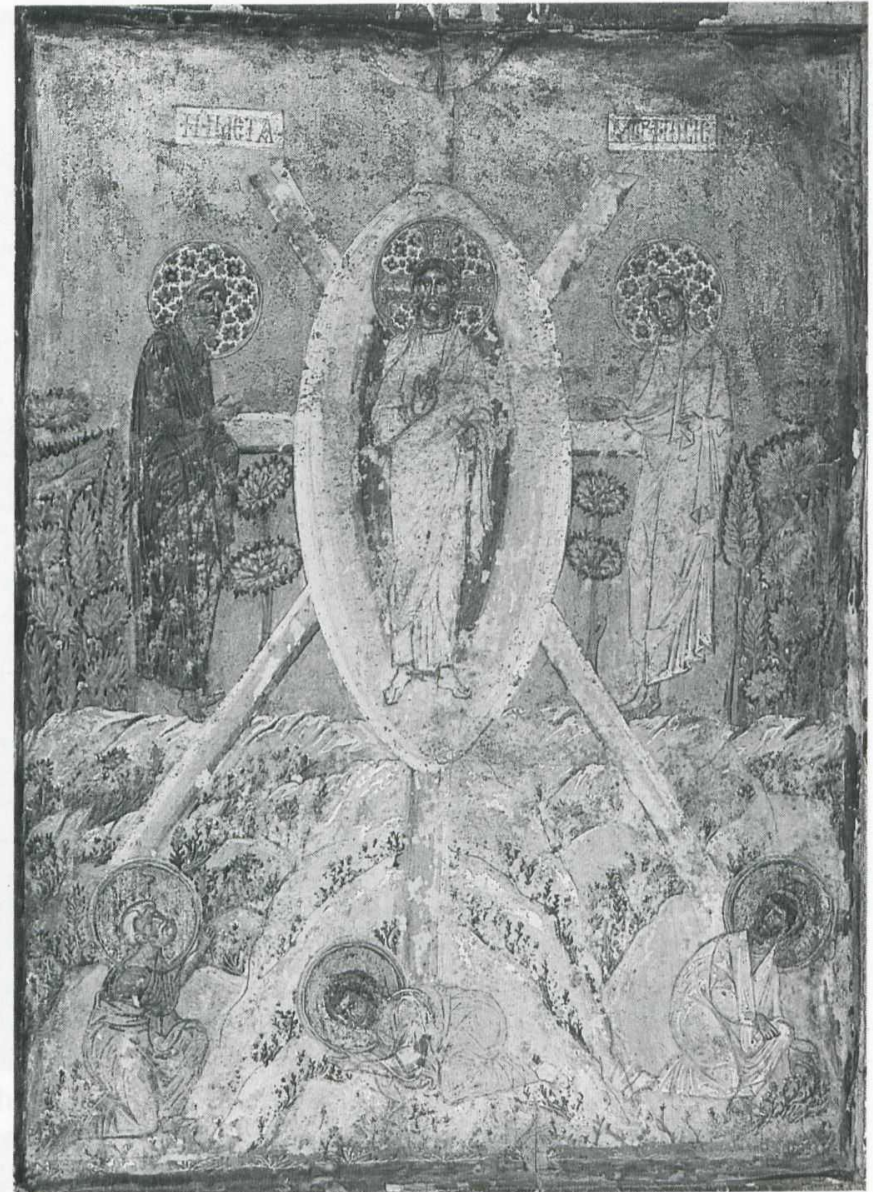

b-Transfiguration, icon. Mount Sinai, Monastery of St Catherine ( $p .45)$

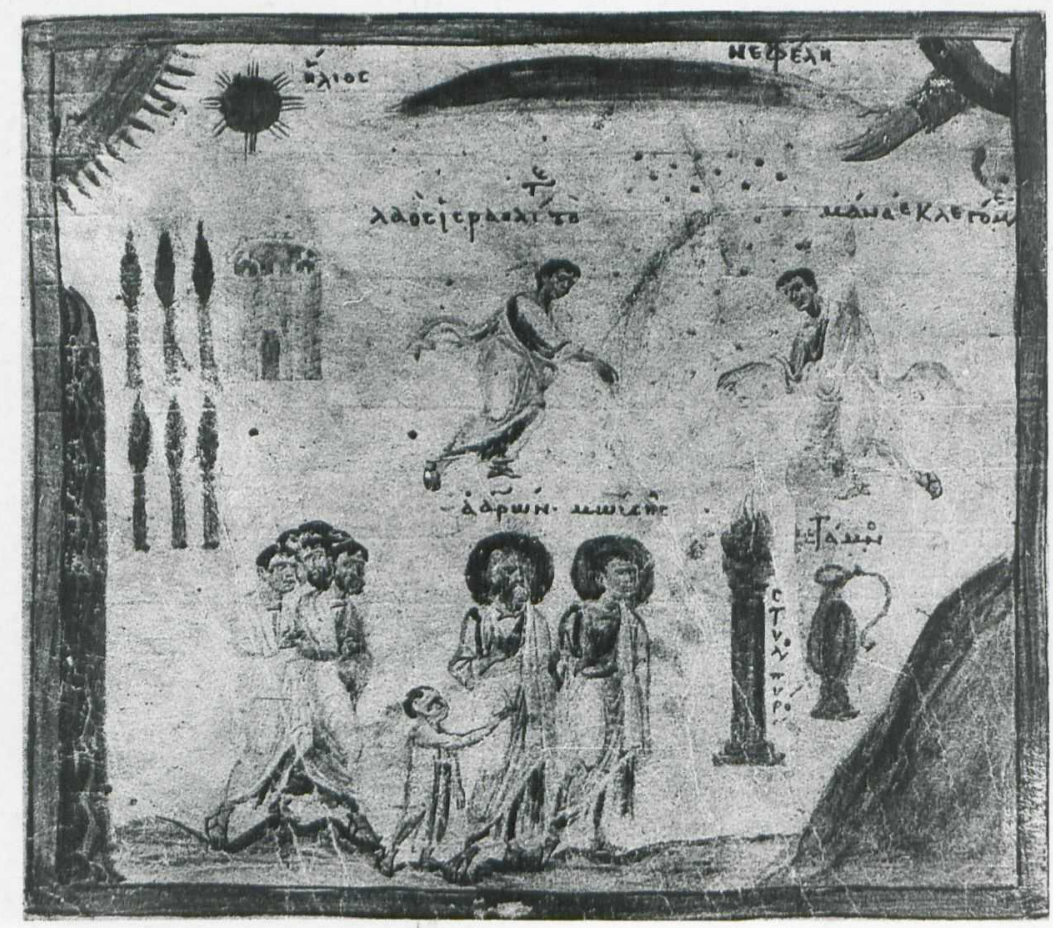

c-Scenes from the Books of Exodus and Numbers. Florence, Biblioteca Laurenziana, MS Plut. 9.28, fol. $103^{\mathrm{v}}(p .47)$ 


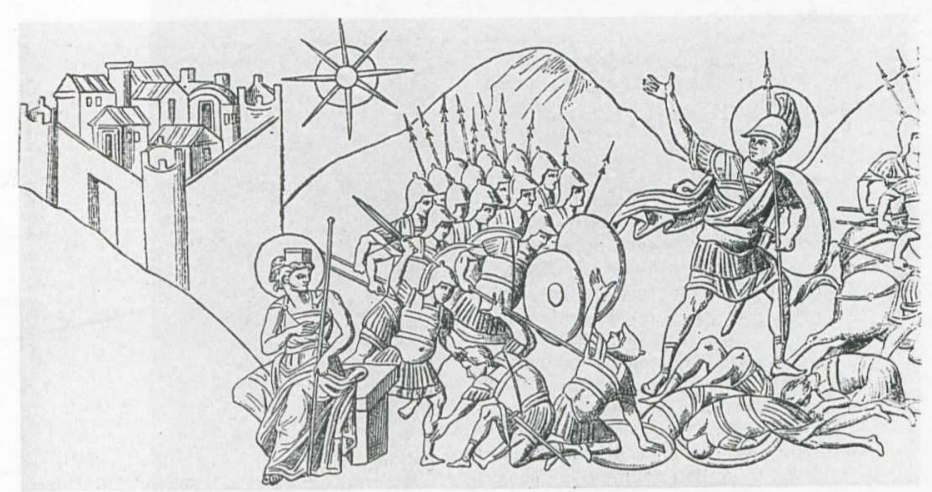

a-Battle between Israelites and Amorites, Joshua Roll. Vatican City, Biblioteca Apostolica Vaticana, MS Palat. gr. 431, sheet XII (detail) ( $p .47$ )

$\mathrm{b}$-Imago solis (fable of the Phoenix). Formerly Smyrna, Evangelical School, Physiologus, p. 22 (detail) ( $p .48$ )

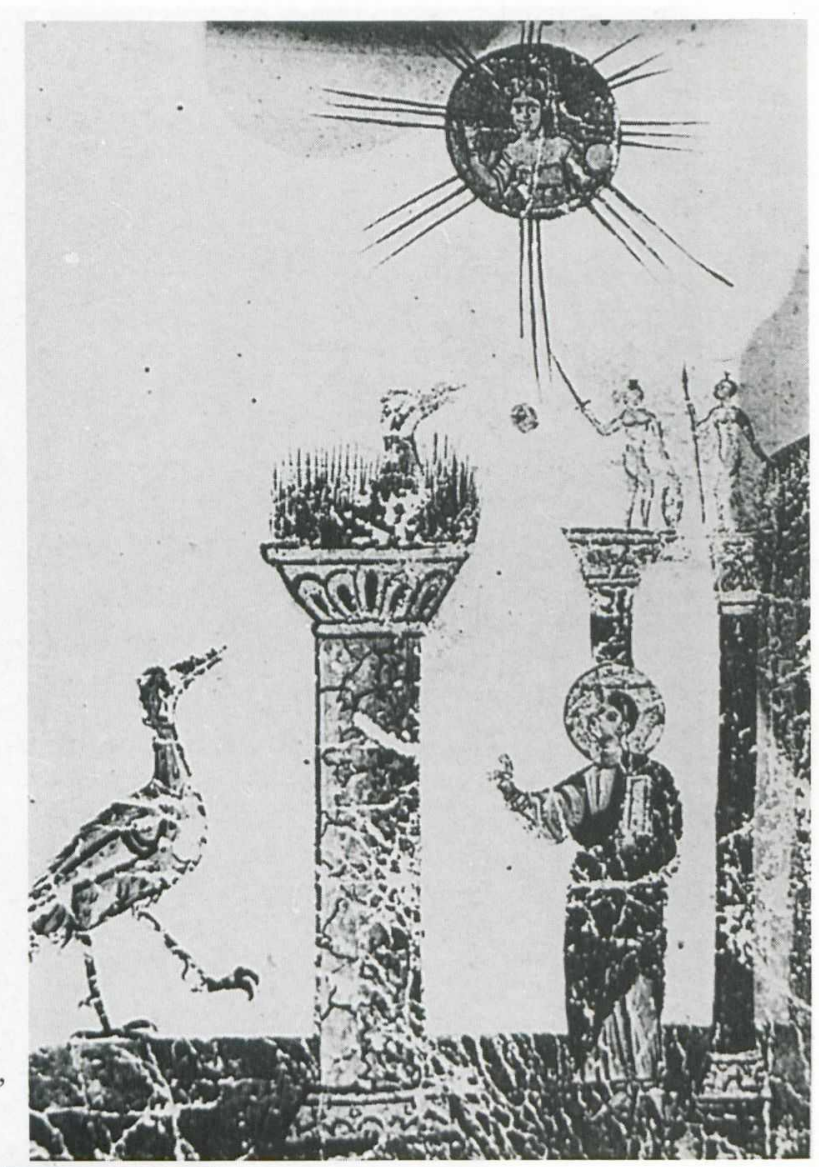

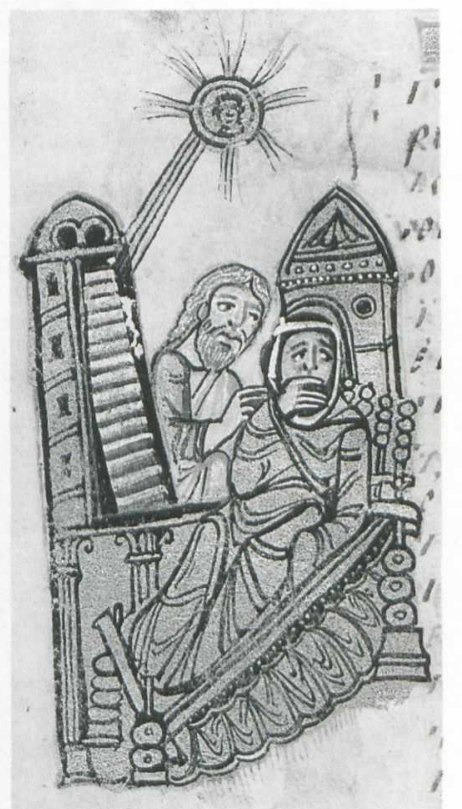

d-Hezekiah's illness. Paris, Bibliothèque Nationale, Sacra Parallela, MS gr. 923, fol. $252^{\mathrm{v}}$ (detail) (p. 48)

\footnotetext{
c-Resurrection, wall-painting. Soganle, church of St Barbara (p. 52)
} 


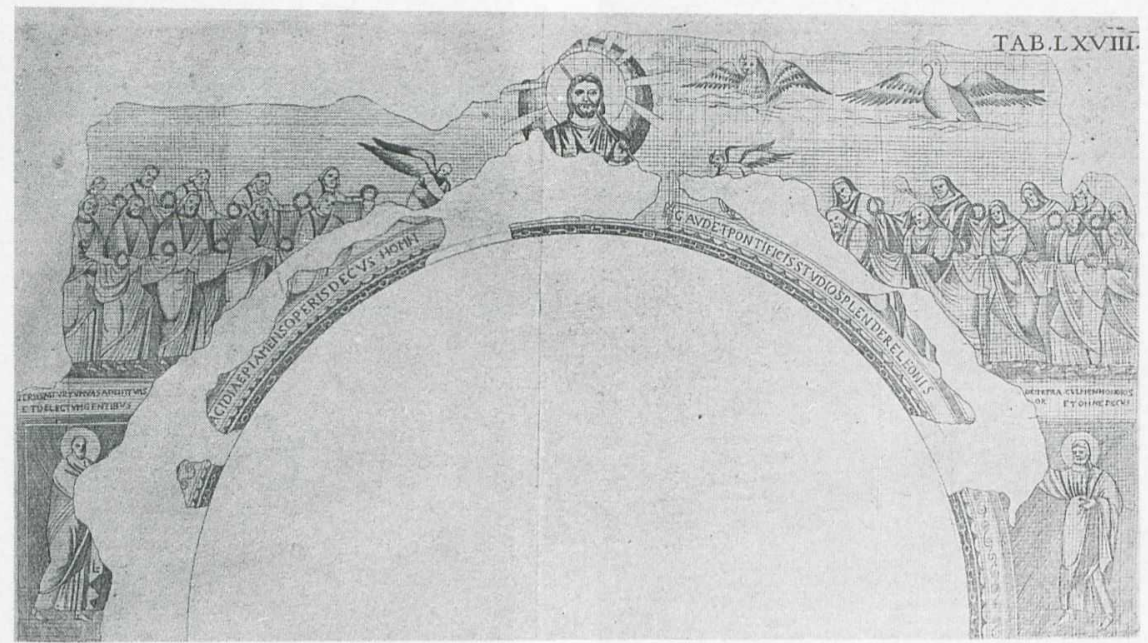

a-Homage of the Elders of Revelation, illustration of mosaic (after Ciampini). Rome, S. Paolo fuori le mura, triumphal arch ( $p .53)$

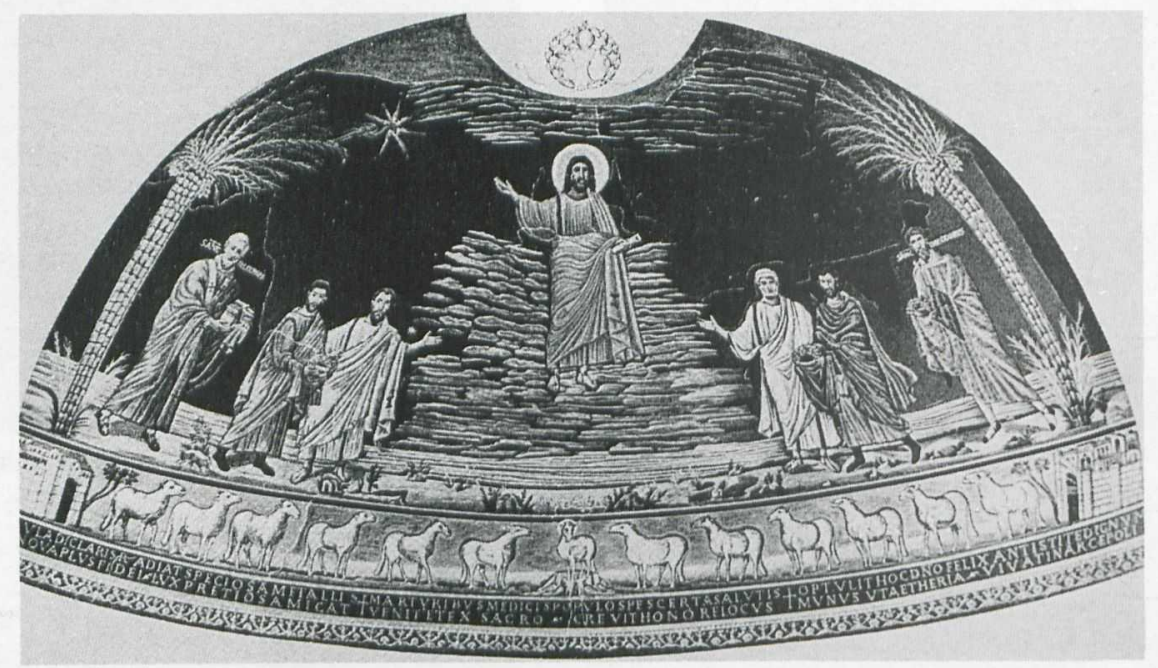

b-Second Coming, mosaic. Rome, SS. Cosma e Damiano, apse (p. 53)

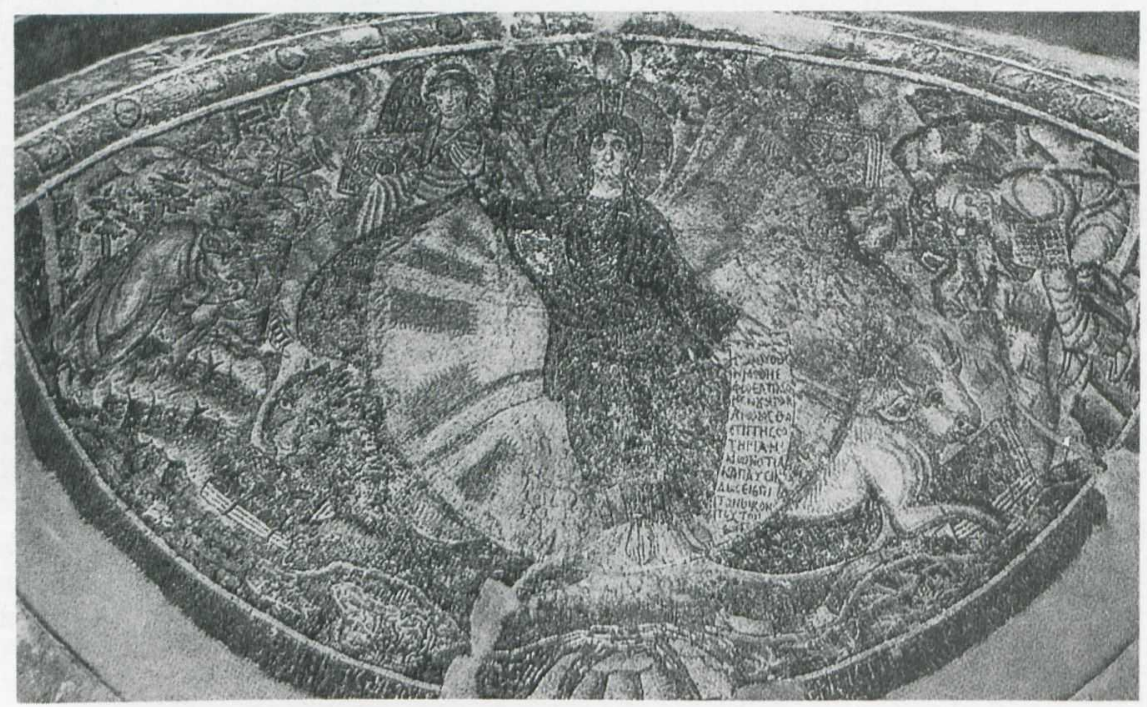

c-Christ in mandorla, mosaic. Thessalonica, Hosios David,

Latomos Monastery, apse ( $p p .54 \mathrm{f})$ 


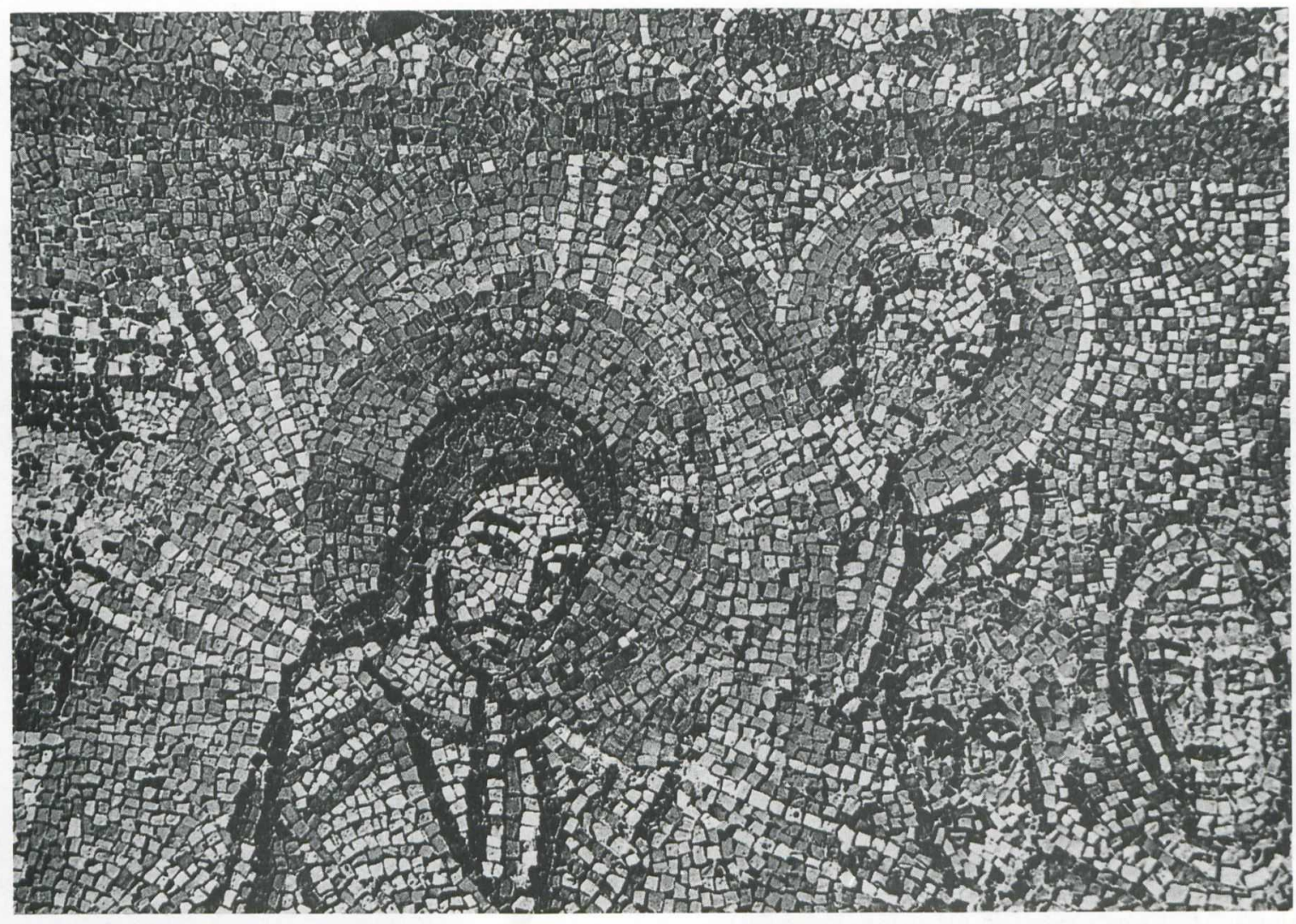

a-Resurrection, mosaic. Rome, S. Prassede, Chapel of S. Zeno, (p. 52)

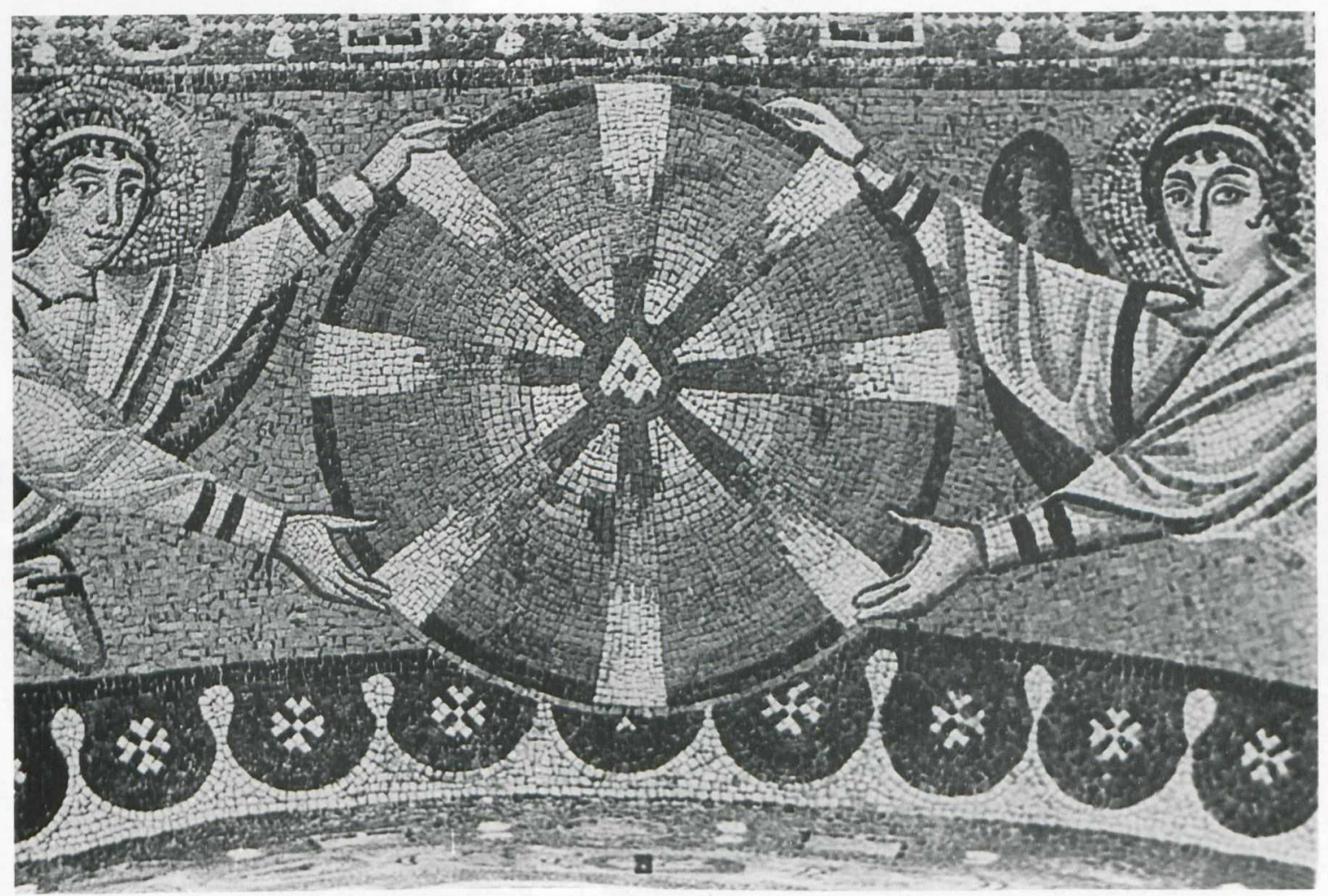

b-Eight-ray motif, mosaic. Ravenna, S. Vitale, triumphal arch, ( $p .59)$ 


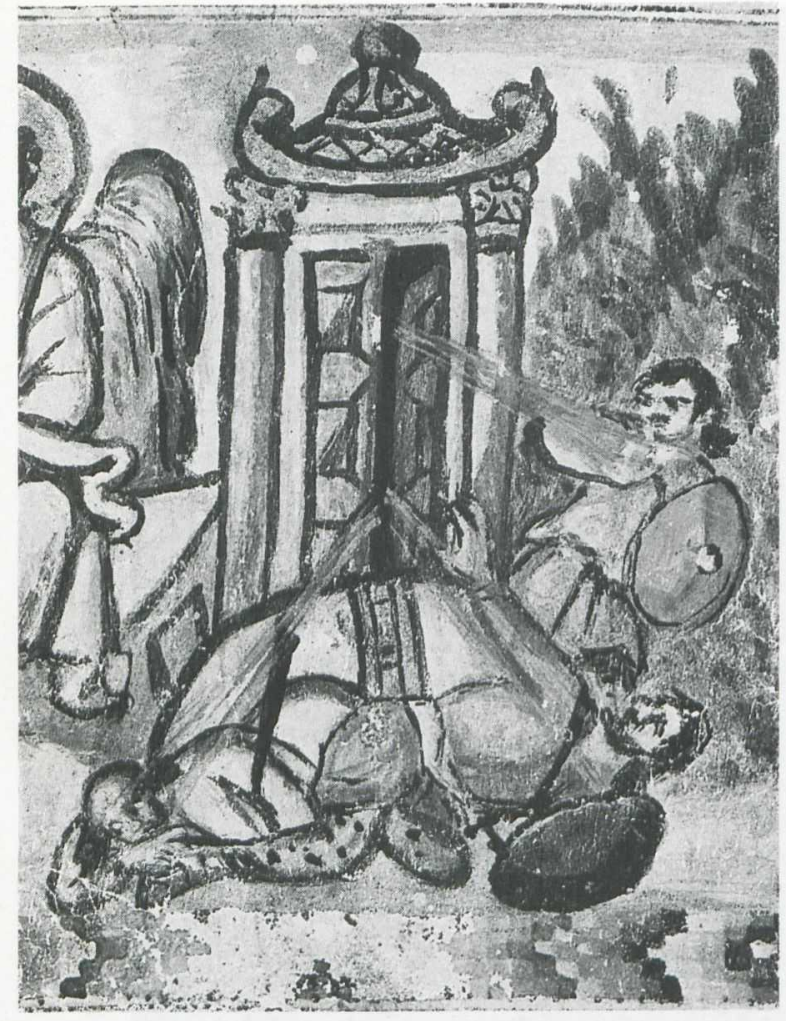

a-Resurrection, Rabbula Gospels. Florence, Biblioteca Laurenziana, MS Plut. 1, 56, fol. 13 ${ }^{\mathrm{r}}$ (detail) (p. 52)

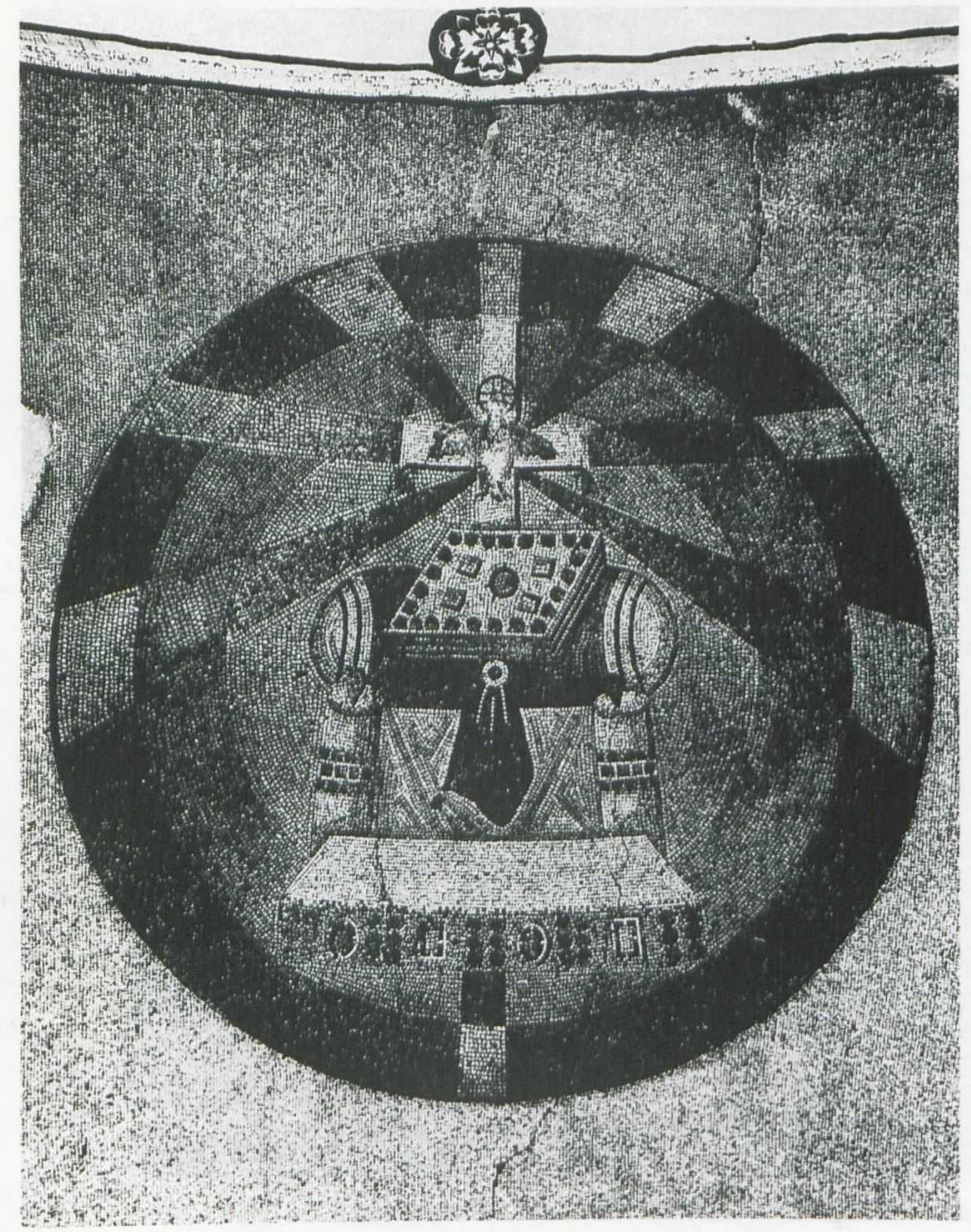

b-Eight-ray motif, mosaic. Formerly Nicaea, Dormition church, bema, $(p .59)$

c-Habbakuk and David witness the theophany, Psalms xlix-1. Moscow, Historical Museum, Chludov Psalter, MS gr. 129, fol. 48v (detail) ( $p p .54 f)$

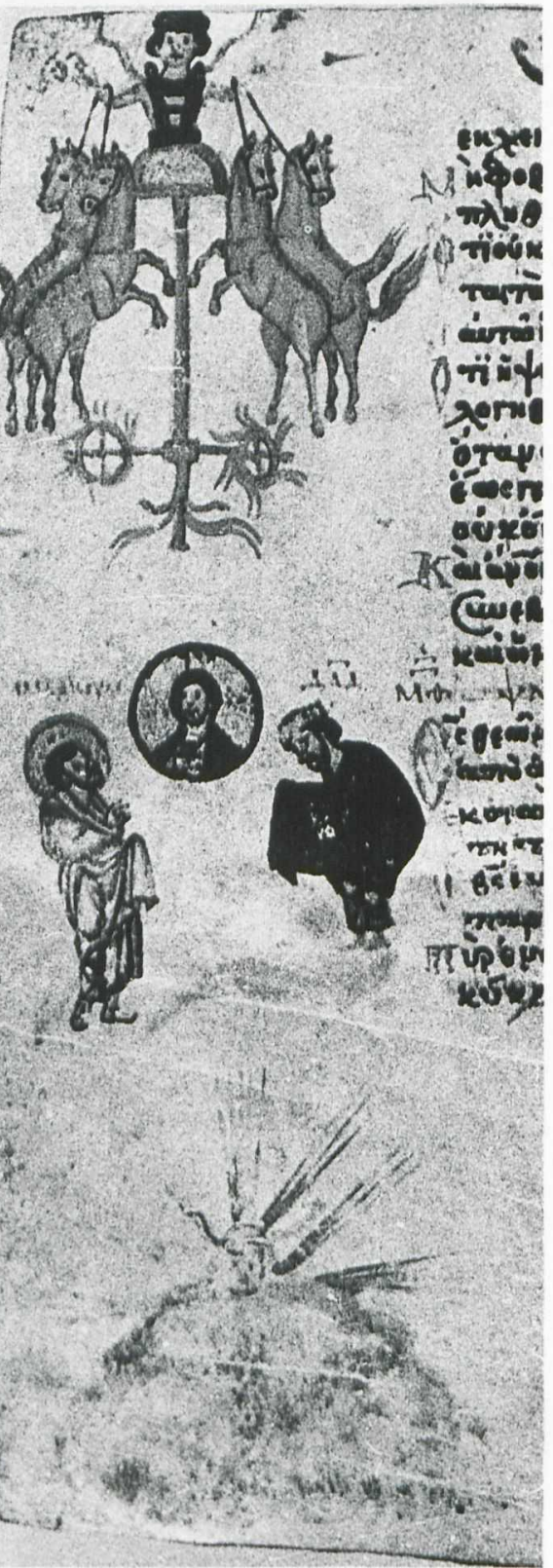

